\title{
An ornithological inventory in a reforested woodlot in western Paraná state, southern Brazil
}

\author{
Isabela Sales Quagliato ${ }^{1,2}$ \& Vagner Cavarzere ${ }^{1,3}$ \\ ${ }^{1}$ Universidade Tecnológica Federal do Paraná (UTFPR), Programa de Pós-Graduação em Recursos Naturais e Sustentabilidade (PPGRNS). \\ Santa Helena, PR, Brasil. \\ ${ }^{2}$ ORCID: http://orcid.org/0000-0003-3407-4721. E-mail: isasquagliato@gmail.com \\ 3 ORCID: http://orcid.org/0000-0003-0510-4557. E-mail: vagnera@utfpr.edu.br
}

\begin{abstract}
This paper presents an ornithological inventory taken between March and December of 2017 in the Brazilian state of Paraná. Although the surroundings contain one relatively well-known location in regard to ornithology, Iguaçu National Park, several other areas merit exploration, among them the Santa Helena Relevant Ecological Interest Area (ARIE-SH). The 1,479 ha ARIE-SH is essentially a large remnant of the Atlantic Forest located adjacent to the city of Santa Helena, Paraná, which commencing in the 1980s has undergone considerable reforestation with both native and exotic species, including fruit species. Prior to censusing bird species and to better characterize the avian community, we conducted a bibliographic review of earlier ornithological studies carried out at ARIE-SH. In addition, we conducted opportunistic and unsystematic observations in nearby locations. We recorded 311 species of birds. During the current inventory, and others conducted in the area since 2016, we recorded six Atlantic Forest endemic species, five species threatened in Paraná, and two globally threatened species. Common species which showed high Index of Frequency in Lists include (in descending order) Basileuterus culicivorus, Leptotila verreauxi, Cnemotriccus fuscatus, Corythopis delalandi, Turdus leucomelas and Arremon flavirostris. Nine species observed while conducting this census (Laterallus exilis, Amazona vinacea, Herpsilochmus Iongirostris, Campylorhamphus trochilirostris, Casiornis rufus, Campylorhynchus turdinus, Myiothlypis flaveola, Eucometis penicillata and Sporophila palustris) are the first records for this region.
\end{abstract}

Keywords. Relevant Ecological Interest Area; Citizen Science; Diamante d'Oeste; Biological Refuge; Santa Helena.

\section{INTRODUCTION}

Scherer-Neto \& Straube (1995) divided the development of ornithology in the state of Paraná into four phases: The "Natterer period" (encompassing all regional ornithological works from the $19^{\text {th }}$ century), the "Chrostowski period" (beginning of the $20^{\text {th }}$ century to the 1930s), the "Mayer Period" (between the 1940s and 1960s) and the "Current Period" (commencing in the 1970s). The most outstanding investigations of the state's wild birds occurred during the first three chronological periods.

The first ornithological investigations of Paraná were conducted by the Austrian naturalist Johann Natterer. During his stay in Paraná between September 1820 and May 1821 he visited numerous localities along its coastal plain (Serra do Mar). He also passed through the state's interior lands west of the Serra do Mar collecting zoological material (Straube, 1993). Between 1921 and 1924, Polish naturalists Tadeusz Chrostowski and Tadeusz Jaczewski, sent by the Polish Museum of Natural History, searched a wide region from the state's center to its far west, as well as along the
Ivaí, Piquiri, and Paraná rivers. During this expedition, they obtained approximately 260 bird taxa, which resulted in the first great ornithological collection for Paraná in this century (Scherer-Neto \& Straube, 1995). In 1930, Emil Kaempfer carried out an extensive ornithological expedition in Paraná. He crossed the state from east to west, collecting material from the coastal plain to the western seasonal forests surrounding Foz do Iguaçu (Straube, 2015, 2016, 2017).

Until the mid-20 $0^{\text {th }}$ century, western Paraná was richly endowed with a variety of bird species, among the most diverse in the Brazilian south and southeast regions (Scherer-Neto et al., 2011). This was largely due to the 180,000 ha of continuous vegetation currently constituting Iguaçu National Park (PNI). This region has been a center of ornithological studies since the $20^{\text {th }}$ century (Scherer-Neto \& Straube, 1995), initiated primarily by naturalists and later by ornithologists investigating the local avifauna community (Straube et al., 2004).

Only $28 \%$ of the original Atlantic Forest vegetation cover still stands (Rezende et al., 2018) and, in Brazil, the remaining forest is now fragmented 
into mostly small ( $<50 \mathrm{ha}$ ), isolated parcels (Ribeiro et al., 2009). Up to the 1960s, a mosaic of large primary forest fragments remained in Paraná's northeast (Gubert-Filho, 2010); however, the current scenario is quite different.

Prior to the $21^{\text {st }}$ century, the avifauna of western and northwestern Paraná (a region which encompasses distinct biomes and types of soil), and especially areas surrounding the Paraná river, was characterized by Sztolcman (1926), Naumburg (1937, 1939), Pinto \& Camargo (1956), Scherer-Neto (1983), Anjos \& Seger (1988) and Straube \& Bornschein $(1989,1995)$. In the current century, studies have focused on the PNI (Straube \& Urben-Filho, 2004; Straube et al., 2004) and more specific reports have been produced (Bencke et al., 2008; Cândido-Jr. et al., 2008; Von Matter et al., 2010; Girardi \& Carrano, 2014; Lindsey et al., 2019).

Our study is intended to compliment the studies noted above by inventorying birds in a little studied, avifauna rich area in Parana: ARIE-SH. Prior to conducting the inventory of ARIE-SH avifauna, we reviewed relevant avifauna information based on literature, citizen science online databases, and natural history museum collections. Less rigorous, non-systematic censuses in locations near ARIE-SH where no previous ornithological studies have taken place were also performed and are included.

\section{MATERIAL AND METHODS}

\section{Study area}

ARIE-SH is the focus of our inventories. ARIE-SH contains 1,479 ha and was once contiguous with the Atlantic Forest semideciduous forests. It is located in the Brazilian state of Parana's southwest, centered on latitude $24^{\circ} 51^{\prime} 04^{\prime \prime} \mathrm{S}$ and longitude $54^{\circ} 21^{\prime} 05^{\prime \prime} \mathrm{W}$, about $1 \mathrm{~km}$ NW of the city of Santa Helena, between Foz do Iguaçu and Ilha Grande National Parks. The entire area of ARIE-SH is surrounded by water, a canal at the southeast margin and a lake at the other mar-

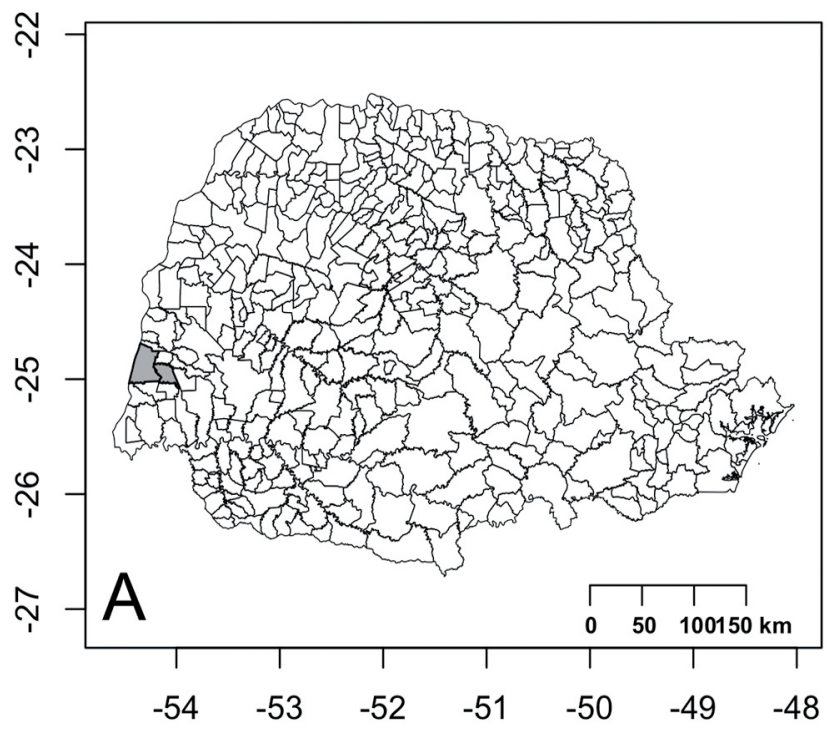

gins. There is a forest opposite ARIE-SH to the west and a reforested strip opposite it to the other compass points, with the water, forest, and reforested strip acting as environmental buffers. Six areas adjacent to ARIE-SH are also non-systematically inventoried (Fig. 1).

Santa Helena County in an area that had experienced rather extreme topographic alteration. Inserted in the hydrographic basins of the Paraná and Iguaçu rivers (western Paraná) located on the left bank (east) of the Paraná river, Santa Helena County (centered at $\left.24^{\circ} 51^{\prime} 37^{\prime \prime} \mathrm{S}, 54^{\circ} 19^{\prime} 58^{\prime \prime} \mathrm{W}\right)$ had about one third $\left(260 \mathrm{~km}^{2}\right)$ of its territory flooded in 1982 after damming of the Paraná river with construction of the Itaipu hydroelectric facility (Cavarzere et al., 2020).

In order to shelter and protect regional flora and fauna, as well as to rescue fauna displaced from its habitat due to the formation of this reservoir, the two nation consortia responsible for Itaipu dam (Brazil and Paraguay) officially created seven ecological reserves (Biological Refuges) in the 1980s, two in Brazil (Bela Vista and Santa Helena) and five in Paraguay (Itabó, Limoy, Carapá, Tati Yupi and Yui Rupá); another one, encompassing both countries (Maracaju Binational Reserve) was also created. One of these reserves was initially named Refúgio Biológico Santa Helena (RBSH) and is entirely within Santa Helena County (Fig. 1). The Refuge had an area of 1,479 ha and is isolated from adjacent areas by an excavated channel and a lake, making it an artificial island (Cavarzere et al., 2020).

RBSH was later reclassified as a Relevant Ecological Interest Area, thereby becoming the Santa Helena Relevant Ecological Interest Area (ARIE-SH), a protected area designated for sustainable use within the legal scope of the National System for Protected Areas (SNUC). As such, it is also a government defined Integral Protected Area designed to preserve water and mineral resources, fauna and flora, with sustainable tourism and scientific research being the only permitted human activities (Brasil, 2002). ARIE-SH is also integrated into the

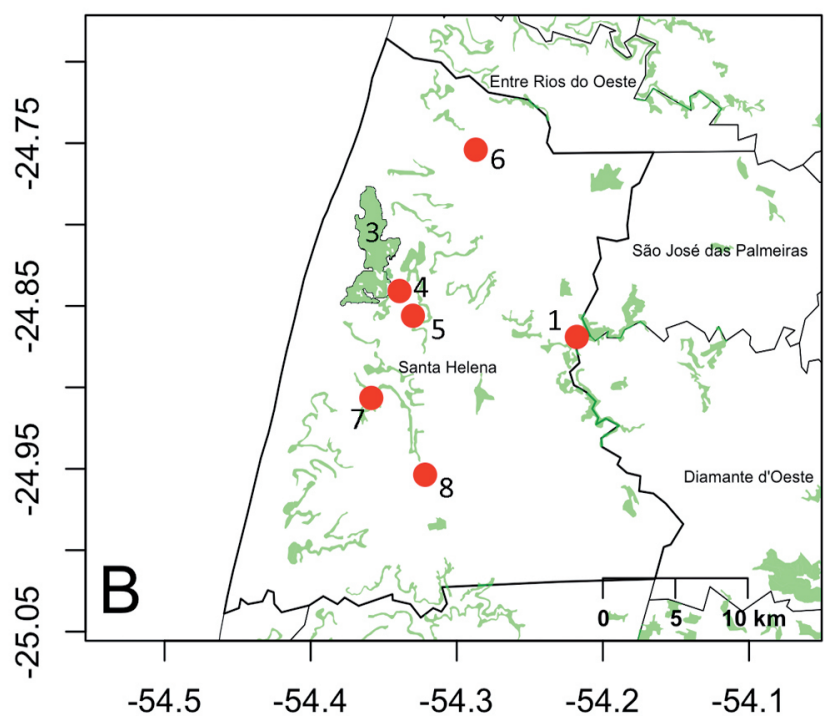

Figure 1. Santa Helena Relevant Ecological Interest Area in relation to the state of Paraná (A) and the counties of Diamante d'Oeste and Santa Helena (B). Green indicates remaining vegetation of over $50 \mathrm{ha}$. 
Paraná Biodiversity Program, which covers more than 2 million ha and connects semideciduous forests to the Araucaria forests along the Iguaçu and Paraná rivers.

According to Koeppen's classification system (Koeppen, 1948; Alvares et al., 2013), the region that includes ARIE-SH is climatically Subtropical Humid Mesothermal ( $\mathrm{Cfa})$, with rainfall distributed uniformly throughout the year (average of 1,650 mm). December and January have the highest average rainfall (150 and $175 \mathrm{~mm}$, respectively), and July and August have the lowest (75 and $100 \mathrm{~mm}$, respectively). The region's average temperature is $22^{\circ} \mathrm{C}$, with highs reaching $40^{\circ} \mathrm{C}$ in the summer and lows down to $-2^{\circ} \mathrm{C}$ in the winter; frosts are infrequent (Kliver, 2010).

\section{Flora}

ARIE-SH was originally covered by semideciduous seasonal forests (IBGE, 2012). By the mid-1970s, a large part of this area had been clear-cut to accommodate agriculture. Since then, more than 6,680 ha of forests have naturally regenerated (Kliver, 2010; Fundação SOS Mata Atlântica, 2020). In 1974 construction began at the Itaipu Binacional hydroelectric dam, $120 \mathrm{~km}$ to the south of Santa Helena. To permit construction of the dam and filling of the lake behind it, the area that includes ARIE-SH was expropriated.

In 1981, reforestation began at what would become ARIE-SH. The reforestation project introduced 18 exotic and 24 native species (eight fruit trees) on 183 approximately $100 \times 50 \mathrm{~m}$ plots. The most used exotic species were Coffee bush Leucaena leucocephala (Lam.) de Wit, Malabar plum Syzygium cumini (L.) Skeels and Rosewood Tipuana tipu (Benth.) Kuntze. The main native species plots were guabiroba Campomanesia xanthocarpa Mart. Ex O. Berg and Brazilian cherry Eugenia uniflora L. More currently, the areas of vegetation have undergone natural regeneration and are in various stages of succession (Kliver, 2010; Tambarussi et al., 2019).

In her study of ARIE-SH, Kliver (2010) noted the predominance of vegetation in the secondary stage of regeneration and that the original native vegetation could be found in small lowland areas with a predominance of herbaceous substrate in soaked soil. More recently, Tambarussi et al. (2019) determined that approximately $74 \%$ of ARIE-SH's area could be classified as an Extensive Use Zone where reforestation with exotics resulted in very poor forest regrowth, $22.4 \%$ classified as being a Natural Zone, 3.3\% classified as being a Recovery Zone, and only $0.1 \%$ classified as an Intangible Zone. When contrasted with areas planted with exotic species, areas that were replanted with native species showed more advanced regeneration, with herbaceous and shrub species occupying the understory, a marked presence of terrestrial ferns, and the richest number of tree species - thus presenting an intermediate successional stage (Tambarussi et al., 2019).

Contrarily, the stands of exotic species show low species diversity in the understory and little natural regener- ation, even after decades of reforestation. Exceptions are the plots with Coffee bush, the seeds of which were used for germination and dispersion studies (Dalmolin et al., 2011). This species is small and leads to an open canopy that allows for the greatest entry of light and the understory's consequent development. With the senescence of the first planted specimens in these plots, space opened for large-scale natural regeneration. Exotics plots with less diversity are those planted with Malabar plum and mango Mangifera indica L., where practically nothing grows in the shaded understory. In these plots, the soil is covered only by thick litter, making it difficult to establish other forms of life. Additionally, allelopathy, systemic with the cultivation of Coffee bush (Scherer et al., 2005) and, especially, Malabar plum, cannot be disregarded as a cause of low regeneration in these areas (Cavarzere et al., 2020).

\section{Reviews}

\section{Literature}

We searched for ornithological records associated with ARIE-SH using databases such as: Directory of Open Access Journals (DOAJ, https://doaj.org), JSTOR (https://www.jstor. org), PubMed (https://www.ncbi.nlm.nih.gov/pubmed), Scielo (https://scielo.org), ScienceDirect (https://www.sciencedirect.com), Scopus (https://www.scopus.com), Web of Science (https://login.webofknowledge.com), and Google Scholar (https://scholar.google.com). We also considered using Google (https://www.google.com) for grey literature.

\section{Online database}

We searched for bird records associated with ARIE-SH until March 27, 2020 on citizen science online databases (critically revising misidentifications), such as Internet Bird Collection (https://www.hbw.com/ibc), Wiki Aves (http://www.wikiaves.com.br), E-bird (https://ebird. org), Xeno-canto (https://www.xeno-canto.org), and Macaulay Library (https://www.macaulaylibrary.org). We used the following keywords: birds, avifauna, ornithology, Biological Refuge Santa Helena, ARIE Santa Helena, and their respective Portuguese translations.

\section{Natural History Museums}

We searched for specimens collected from ARIE-SH and Santa Helena County in the Museu de História Natural Capão da Imbuia (MHNCl), and Museu de Zoologia da Universidade de São Paulo (MZUSP).

\section{Bird census}

\section{Land birds}

About 15 min before sunrise we inventoried the land birds of ARIE-SH on pre-existing trails for a total of 14 one-day visits (which lasted for $3 \mathrm{~h}$ each) between March 
Table 1. Dates of censuses conducted on trails and along the margins of the Santa Helena Relevant Ecological Interest Area in 2017.

\begin{tabular}{ccc}
\hline Campaign & Date & Census type \\
\hline I & March $10^{\text {th }}$ & land \\
II & March $24^{\text {th }}$ & land \\
III & May $12^{\text {th }}$ & land \\
IV & May $13^{\text {th }}$ & land \\
V & May $25^{\text {th }}$ & land \\
VI & July $9^{\text {th }}$ & land \\
VII & June $21^{\text {st }}$ & water \\
VIII & June $23^{\text {rd }}$ & water \\
IX & July $31^{\text {st }}$ & water \\
X & August $31^{\text {st }}$ & water \\
XI & September $30^{\text {th }}$ & water \\
XII & November $11^{\text {th }}$ & water \\
XIII & November $15^{\text {th }}$ & land \\
XIV & December $15^{\text {th }}$ & water \\
\hline
\end{tabular}

and December of 2017 (Table 1). We used 5-species lists (Mackinnon \& Phillips, 1993) when the observer takes notes of all seen or heard species. Each list contains five species, and one species cannot be repeated in the same list but can appear in subsequent ones. We generated Index of Frequency in Lists (IFL) by dividing the number of lists in which a given species occurred by the total number of accumulated lists (Ribon, 2010).

\section{Water birds}

We inventoried the water birds linked with ARIE-SH following the Scott \& Carbonell (1986) directory who used the Ramsar Convention, which suggests that water birds are those that depend on wetlands, to determine the families and, consequently, the species of aquatic avifauna. Except for time of beginning censuses, we deliberately used Lara's (1994) methodology so that water bird communities could be compared over an interval of approximately 33 years. We determined transects around the ARIE-SH perimeter ( $32 \mathrm{~km}$ ) and navigated by motorized boat at a constant speed of about $5 \mathrm{~km} / \mathrm{h}$, covering a total of $256 \mathrm{~km}$ in all campaigns (Table 1). Inventorying took place between 13:00 and 17:00, starting on the eastern margin, going around ARIE-SH's perimeter, and ending on its western margin. On a rainy day (September 30), we were forced to interrupt the inventory at the halfway point. The same observers (ISQ and VC) conducted censuses using $8 \times 20$ and $8 \times 42$ binoculars. Whenever pos- sible, we photographed species and taped their vocalizations with a digital recorder and directional microphone.

\section{Qualitative census}

We additionally took occasional, non-systematic observations at six locations close to ARIE-SH (Fig. 1, Table 2).

\section{Analysis}

We used the Jaccard Similarity Index defined according to Krebs (1989) to compare the aquatic bird community over an interval of approximately 33 years,

$$
S_{j i}=\frac{a}{a+b+c}
$$

where $S=$ Jaccard Similarity Index between campaigns $i$ and $j ; a=$ number of species that occur in both campaign $i$ and campaign $j$ (co-occurrence); $b=$ number of species that occur in campaign $j$ but are absent in campaign $i ; c=$ number of species that occur in campaign $i$ but are absent in campaign $j$. We did not compare the terrestrial community between periods due to the heterogeneity of methodologies used in relevant studies and the fact that the present censuses did not sample the entire ARIE-SH area.

We used the Vegan package (Oksanen et al., 2007) within the R environment ( $R$ Core Team, 2019) to build species accumulation curves and calculate the similarity index. We further used the warbleR package (Araya-Salas \& Smith-Vidaurre, 2017) to present the spectrogram.

We used the proposal by Piacentini et al. (2015) for bird taxonomy. Atlantic Forest endemic bird species are in agreement with Vale et al. (2018) and threat status follows global (IUCN, 2019), national (Brasil, 2014) and state (Paraná, 2018) references.

\section{RESULTS}

\section{Reviews}

\section{Literature}

Scherer-Neto's (1997) data provided the foundation for our ARIE-SH avifauna information. The author ob-

Table 2. List of counties and cities near the Santa Helena Relevant Ecological Interest Area where sightings occurred, cumulative hours of non-systematic observations and their respective decimal coordinates.

\begin{tabular}{|c|c|c|c|c|c|c|}
\hline & Municipality & Location & Accumulated hours & Visits & Latitude & Longitude \\
\hline 1 & Diamante d'0este County & Coluna Prestes & 20 & 2019 & -24.87 & -54.22 \\
\hline 2 & Palotina City & UFPR campus (not on map) & - & 2016 & -24.28 & -53.83 \\
\hline 3 & Santa Helena County & ARIE-SH & 40 & 2016-2019 & -24.26 & -54.32 \\
\hline 4 & Santa Helena City & UTFPR campus & 200 & $2016-2020$ & -24.84 & -54.34 \\
\hline 5 & Santa Helena City & Downtown & 5 & $2016-2020$ & -24.86 & -54.33 \\
\hline 6 & Santa Helena County & Morro dos Sete Pecados/Subsede & 5 & 2016-2019 & -24.75 & -54.29 \\
\hline 7 & Santa Helena County & Sítio Paraná & 5 & $14 / 03 / 20$ & -24.91 & -54.36 \\
\hline 8 & Santa Helena County & Rural site & 5 & 2017 & -24.95 & -54.32 \\
\hline
\end{tabular}


tained a total of 143 species over four campaigns carried out every three months. During each campaign, the author covered ARIE-SH trails over three consecutive days (but also in adjacent areas, therefore, outside the ARIE-SH), alternating the starting points between the beginnings and the ends of the trails. He recorded bird species using transect counts and mist-netting and carried out transects in different environments.

In a study restricted to water species, Lara (1994) also inventoried locations near ARIE-SH, observing 28 bird species specifically at ARIE-SH. The author censused every three months over one year using the method we chose to use to census water birds.

Censusing at both ARIE-SH and at the Bela Vista Biological Refuge (RBBV) in the county of Foz do Iguaçu, Paraná, Seger et al. (1993), including Scherer-Neto's (1997) records, logged a total of 280 bird species but did not distinguish between the two locations in their records.

The most recent available ARIE-SH avifauna data are from Kliver's (2010) inventoried carried out in 1998 and in 2010. The author recorded 269 (24 orders and $61 \mathrm{fam}$ ilies) species in 1998 and 197 (20 orders and 51 families) species in 2010, for a total of 271 species in 24 orders and 62 families. Between October 2009 and January 2010, the author conducted 80 visits to ARIE-SH at different times of the day, with a mean duration of 1.5 hours each. Observers carried out transects covering $53 \mathrm{~km}$ of trails with a constant speed of about $1.5 \mathrm{~km} / \mathrm{h}$. Kliver (2010) followed the same sequence on transects, alternating days of drought and rain and censusing during the mornings and afternoons.

\section{Online database}

As of March 27, 2020, only Wiki Aves showed bird records (97 species) from Santa Helena County. However, the data supplied by the citizen scientists did not accurately report observation locations; we therefore did not incorporate Wiki Aves records in our compilation.

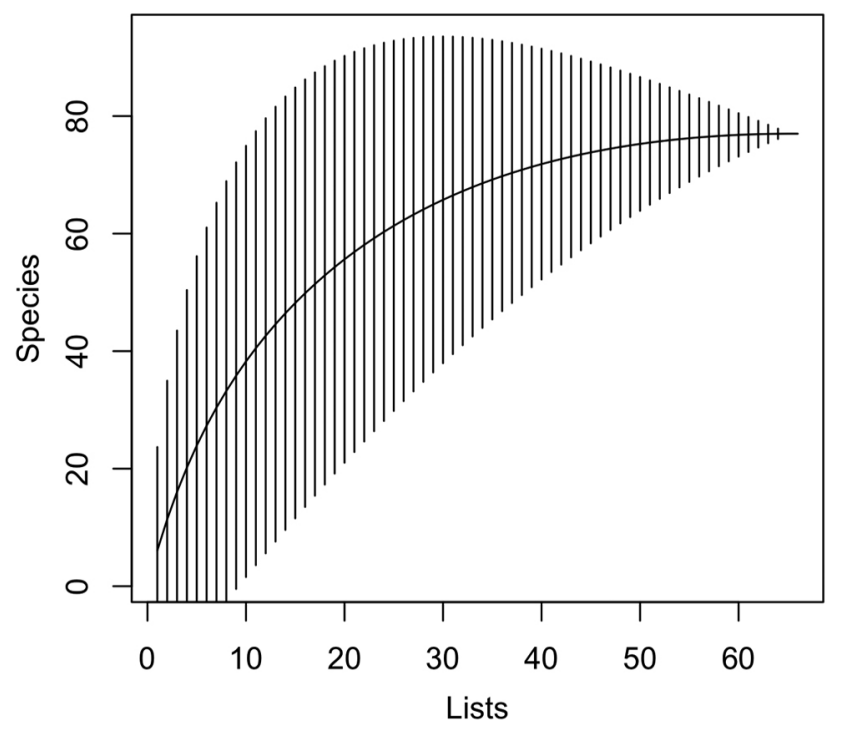

Figure 2. Accumulation curve of species recorded during terrestrial census at the Santa Helena Relevant Ecological Interest Area, Santa Helena County.

\section{Natural History Museums}

We found two specimens (MZUSP 75893 and MZUSP 75894) of Great Dusky Swift Cypseloides senex collected on April 28, 1982 at the mouth of the São Francisco Falso River in Santa Helena County, as well as another eight species from Santa Helena housed at $\mathrm{MHNCl}$, of which four were collected at ARIE-SH between 1987-1991 (Appendix).

\section{Bird census}

We recorded a total of 125 bird species in at ARIE-SH using two methodologies. Three species are Atlantic Forest endemics (Aramides saracura, Picumnus temminckii, and Tachyphonus coronatus) and one is endangered at state level (Busarellus nigricollis). We recorded no nationally or globally threatened species at ARIE-SH.

\section{Land birds}

We accumulated 65 five-species lists, recording 78 species while hiking trails at ARIE-SH. Two Atlantic Forest endemic forest species were recorded only during the land bird census (P. temminckii and T. coronatus). The species accumulation curve shows a tendency towards stabilization (Fig. 2). IFL values varied from one (0.016) to 23 (Basileuterus culicivorus, 0.359) records in lists (Appendix).

\section{Water birds}

During the inventories taken while traveling around the shore of ARIE-SH, we recorded 74 species in 15 orders and 32 families. Twenty-two of the birds recorded were "water birds" as defined following Scott \& Carbonell's (1986) classification of aquatic birds. We recorded the regionally endangered Busarellus nigricollis exclusively on

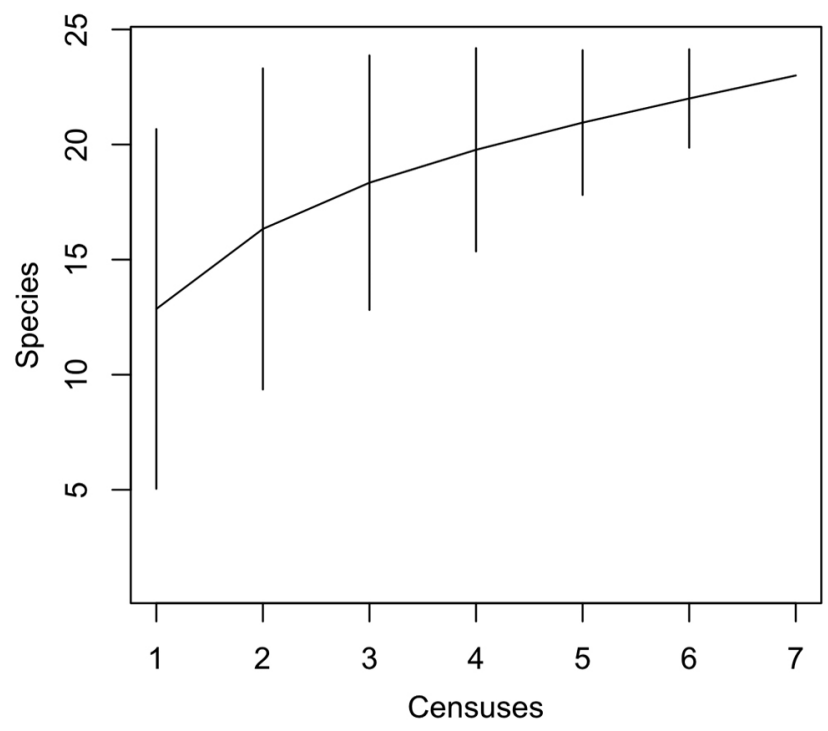

Figure 3. Accumulation curve of aquatic species recorded on the margins of the Santa Helena Relevant Ecological Interest Area, Santa Helena County. 
ARIE-SH's margins. The species accumulation curve for aquatic species did not show stabilization (Fig. 3).

\section{Qualitative census}

Our records (including occasional, non-systematic observations) and compilations resulted in the identification of 311 bird species for ARIE-SH and surroundings. The number of endemic species rises to six ( $A$. saracura, P. temminckii, Amazona vinacea, Automolus leucophthalmus, Myiornis auricularis and T. coronatus). Regarding state level threatened species, we compiled one critically endangered species (Sporophila palustris), one endangered species ( $B$. nigricollis) and four vulnerable species (A. vinacea, Campylorhamphus trochilirostris, Casiornis rufus and Sporophila leucoptera). At the national level, no threatened species were encountered. At the global level, two species are listed as endangered ( $A$. vinacea and S. palustris). We recorded 17 species in the area that had not been registered (Appendix).

\section{Analysis}

Lara (1994) recorded 28 aquatic bird species (eight exclusive) while we detected 22, of which two were only recorded by us (Table 3 ). The similarity index between current and previous water bird censuses was $\mathrm{Sji}=0.67$.

\section{DISCUSSION}

There are a few exceptional preterit records which merit mention as they are no longer present regionally, such as the Scaled Pigeon Patagioenas speciosa and the Crested Eagle Morphnus guianensis, both obtained

Table 3. List of aquatic bird species recorded within ARIE-SH in previous (Lara, 1994) and recent censuses.

\begin{tabular}{lll}
\hline Common to both studies & \multicolumn{1}{c}{ Lara (1994) } & \multicolumn{1}{c}{ This study } \\
\hline Dendrocygna viduata & Anhinga anhinga & Dendrocygna bicolor \\
Cairina moschata & Nycticorax nycticorax & Podilymbus podiceps \\
Amazonetta brasiliensis & Bubulcus ibis & \\
Nannopterum brasilianus & Aramides cajaneus & \\
Butorides striata & Charadrius collaris & \\
Ardea cocoi & Tringa flavipes & \\
Ardea alba & Calidris fuscicollis & \\
Egretta thula & Sternula superciliaris & \\
Aramus guarauna & \\
Aramides saracura & \\
Pardirallus nigricans & \\
Gallinula galeata & \\
Porphyrio martinicus & \\
Vanellus chilensis & \\
Himantopus melanurus & \\
Tringa solitaria & \\
Jacana jacana & \\
Megaceryle torquata & \\
Chloroceryle amazona & \\
Chloroceryle americana & \\
\hline
\end{tabular}

in Marechal Cândido Rondon, some 25 km east of Santa Helena (Straube \& Bornschein, 1989, 1995). Another important record is that of the Large-tailed Antshrike Mackenziaena leachii, obtained in Foz do Iguaçu, Pato Bragado, Marechal Cândido Rondon and Guaíra by Kaempfer (Naumburg, 1937). The Plumbeous Pigeon P. plumbea is also worth mentioning, deposited at $\mathrm{MHNCI}$ and currently quite rare in interior Paraná. Some 100 km further east, Pinto \& Camargo (1956) presented several species collected in Porto Camargo (Icaraíma municipality), such as the Undulated Tinamou Crypturellus undulatus, the Three-toed Jacamar Jacamaralcyon tridactyla, the Helmeted Woodpecker Celeus galeatus, the Black-capped Antwren Herpsilochmus atricapillus, the Russet-mantled Foliage-gleaner Syndactyla dimidiata and the Crested Oropendola Psarocolius decumanus. Scherer-Neto et al. (1997) reported three important (undocumented) singletons: White-browed Woodpecker Piculus aurulentus, Rufous-headed Tanager Hemithraupis ruficapilla and Green-throated Euphonia Euphonia chalybea, Atlantic Forest endemics which currently do not have records in this region of the state. Such species are of paramount importance for characterizing the avifauna once present. Therefore, they indicate community composition changes which resulted from habitat modification.

\section{Reforestation}

ARIE-SH lies approximately $80 \mathrm{~km}$ northeast from PNI, an area containing 335 bird species (Straube et al., 2004). This great species richness is a reflection of PNI's large size, abundant native vegetation and diversity of habitats, which include mixed and seasonal forests. However, because ARIE-SH and PNI are close to one another and share a seasonal forest biome, their avifauna compositions should have been similar before ARIE-SH was deforested (Willis, 1979). In addition, small ( $\geq 20$ ha) reforested seasonal semideciduous Atlantic Forest remnants in northern Paraná do have equal or higher bird richness and similar functional group structures when compared to contiguous native vegetation. Thus, they can maintain levels of biodiversity and reduce species extinction debt (Santos-Júnior et al., 2016). Furthermore, as long as contiguous to native fragments, interior Atlantic Forest reforested areas in São Paulo state with native and exotic plant species proved to be ecologically more functional for birds and to contribute to the maintenance of resident and visiting species by providing food resources (Athiê \& Dias, 2012). Since we recently recorded only 125 species within ARIE-SH, we present a few arguments why such differences currently occur.

Some trophic guilds-specialized forest species, such as large frugivores and understory insectivores, tend to disappear from degraded environments (Willis, 1979; Ribon et al., 2003). Some of these species were only recorded in past ARIE-SH censuses, such as the large frugivores Crypturellus obsoletus and Penelope superciliaris. The former, a terrestrial species having low sensitivity to forest fragmentation (Anjos, 2006), uses small forest remnants (10 ha) as long as there is continuous connec- 
tion among forest patches (Barbosa et al., 2017). Because there is continuous reforested vegetation bordering the eastern margins of the lake connecting ARIE-SH to PNI, this species' absence strongly suggests habitat modification. Although Penelope superciliaris avoids habitat modification (Pereira-Ribeiro et al., 2018), it can be found in small forest remnants (Anjos, 2001) and even in disturbed ones (pers. obs.). Both $C$. obsoletus and $P$. superciliaris are game birds and, especially in the case of $P$. superciliaris, invite intense poaching activity, which may play a major role in their dearth (Pereira-Ribeiro et al., 2018). This conclusion is corroborated by the fact that $P$. superciliaris was quickly sighted during our visits to nearby locations (Appendix) that do not suffer the hunting pressure. The ecological consequences of this species absence are of paramount importance as both species are able to swallow fruits with large seeds that smaller bird species cannot disperse, greatly contributing to the fruit's trees spreading throughout its environment (Pizo, 2004).

Dendrocolaptids and thamnophilids are examples of understory insectivorous. Species belonging to this tropic guild are among the first to disappear from forest fragments at the earliest sign of habitat modification (Stouffer et al., 2011). Therefore, a more permeable matrix facilitates their dispersal within landscapes. Not only matrices, but passive restoration, is a cheap and effective solution to recover some taxocenes in the Atlantic Forest (Guerrero \& Rocha, 2010). We did not record any dendrocolaptid species and only three thamnophilids, with $T$. caerulescens being the most common. This species is less sensitive to forest fragmentation (Ribon et al., 2003; Anjos, 2006), occurring in several small fragments (Barbosa et al., 2017) and, apparently, is not affected by changes in the vegetation's structure at ARIE-SH.

In an area of similar size to ARIE-SH in the municipality of Rio Claro, São Paulo state, a Eucalyptus sp. woodlot with native understory in interior São Paulo state, the bird community is impoverished when compared with a 10-times smaller native remnant (Willis, 2003), a trend in Neotropical forests (lezzi et al., 2018). The fact that non-deciduous tree species (permanent canopy cover precluding the passage of sunlight) have been used for the reforestation of ARIE-SH resulted in the absence of a native understory. A clear understory contributes to the loss of bird species in such environments, as already reported for the Brazilian state of Espírito Santo (Marsden et al., 2001) and for Argentina (lezzi et al., 2018). Although Eucalyptus sp. forests can be important within a matrix context, meaning bird species can use them to move among fragments (Barbosa et al., 2017), this is not the case in ARIE-SH, which is surrounded by water and in extremely close proximity to monocultures on the east, such as soybean and maze. Because large-scale (at least 10-year-old) tree planting in corridors adjacent to mature forests results in rapid increased abundance and expanded distribution of forest birds (Pejchar et al., 2018), we draw attention to the need to investigate whether the plant species used for reforestation are adequate for fauna usage of the protection strip bordering Itaipu dam and whether it is being used for travel among National Parks.
Although other empirical studies have observed that habitat modification can lead to an absence of specialist species, it is possible that the noted absence of a species in ARIE-SH is due to recording error or observational failure and that the species was present. Observational failure can be caused by (1) imperfect detection, especially evident when the chance of detecting a species is less than 1 (Mackenzie et al., 2017), or (2) because the species are in ARIE-SH microhabitats that we did not visit.

\section{Similarity}

The Similarity Index between the composition of the aquatic avifauna found by Lara (1994) suggests that almost $70 \%$ of the aquatic avifauna remained the same at ARIE-SH. This index is relatively high when compared to those found by da Da Silva-Jr. (2007), who monitored bird composition within the Caiapó River Valley in the state of Goiás, pre- and post-filling of small lakes behind two dams. The author obtained $\mathrm{Sji}=0.23$, an expressive, but expected, dissimilar result since the author censused bird communities during completely different times: before and after damming.

Lara (1994) visited ARIE-SH some five years after Itaipu dam began filling up. Then, microhabitats which are not currently found, may have been present, such as sand beaches suitable for finding several piper species. We only recorded groups of the White-backed Stilt Himantopus melanurus (not on beaches, but afloat on macrophytes) and lone individuals of Solitary Sandpiper Tringa solitaria, while Lara (1994) could find another three of these migratory species. In addition, the author detected the Cattle Egret Bubulcus ibis, a very common species in pastures which we did not see on aquatic environments. Apart from the Gray-necked Wood-Rail Aramides cajaneus, commoner to the northeast of the state (Scherer-Neto et al., 2011), the remaining species we did not record within ARIE-SH were actually seen by us in similar habitats on other locations in the municipality. Similarly, the two species Lara (1994) failed to detect during her censuses probably result from randomness.

\section{Species accounts}

Busarellus nigricollis (Black-collared Hawk): Considered endangered in Paraná (Paraná, 2018). This species occurs in almost all of Brazil (Bierregaard et al., 2020), but there are few records of its presence in Paraná. We saw a lone individual on the shores of Lake Itaipu in a bay with exposed stumps surrounded by riparian vegetation $\left(24^{\circ} 47^{\prime} 46^{\prime \prime} \mathrm{S}, 54^{\circ} 21^{\prime} 56^{\prime \prime} \mathrm{W}\right)$ in June, August, September and November (Fig. 4). There was an abundance of aquatic macrophytes observed, such as Eicchornia spp. and Salvinia sp. First recorded in Paraná in Altônia in 1989 (Straube \& Bornschein, 1995), some five years after Itaipu lake damming. No collector found this large and conspicuous species in this region before, which suggests a 


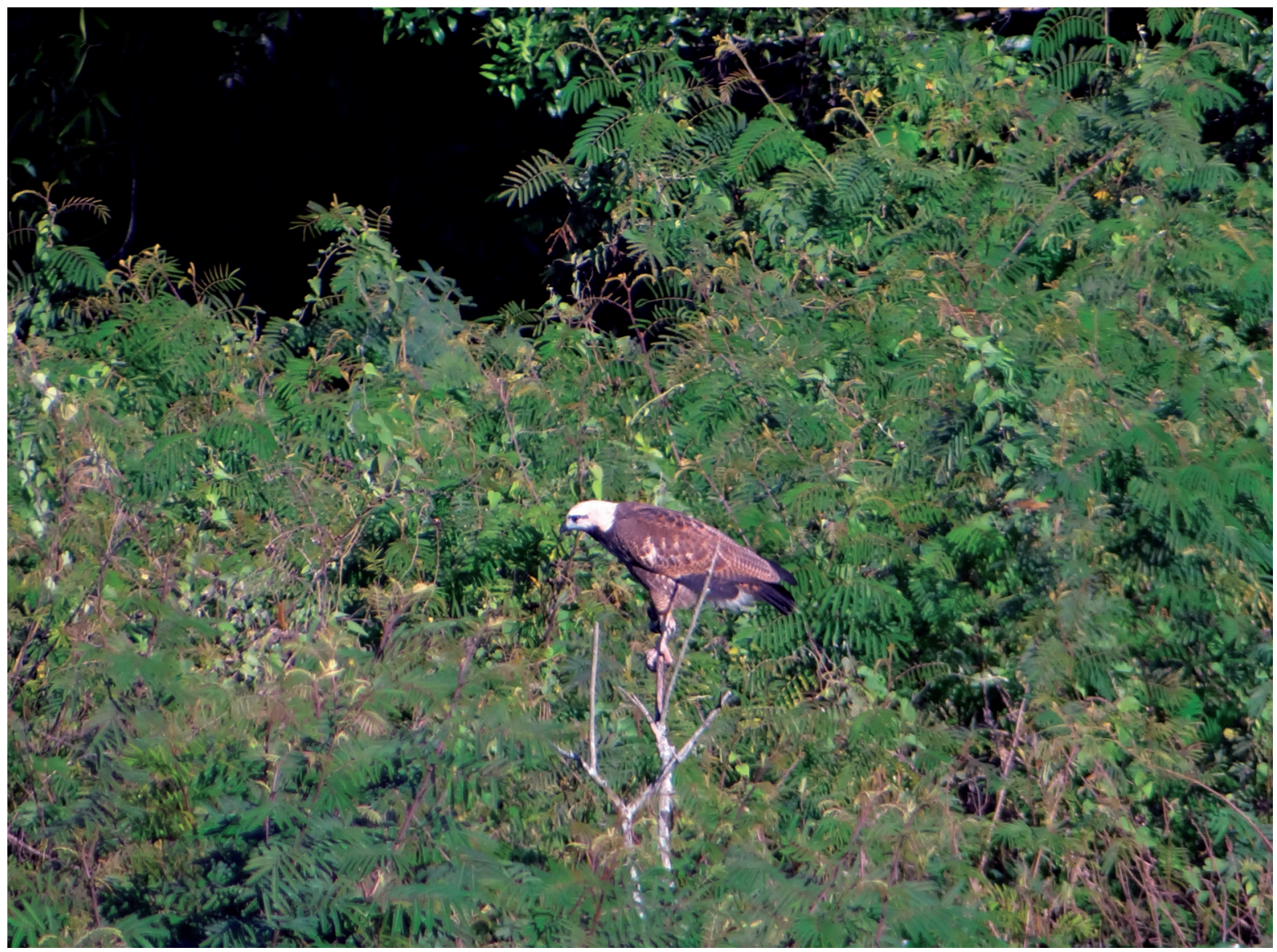

Figure 4. Individual of Busarellus nigricollis photographed at Santa Helena Relevant Ecological Interest Area, Santa Helena county. Photo: Vagner Cavarzere.

recent distribution expansion in the state due to water habitats (absent before damming) created by Itaipu dam. Currently, the species seem to occur almost exclusively on the banks of the Paraná (Scherer-Neto \& Straube, 1995) and Paranapanema rivers.

Laterallus exilis (Gray-breasted Crake): Data deficient in Paraná (Paraná, 2018). It has been observed in the southern region of the Brazilian Amazonia, eastern Brazil (Taylor, 2020) and in northeastern Argentina (Pearman et al., 2000). We skinned an individual who collided with a wall of a UTFPR - Santa Helena faculty

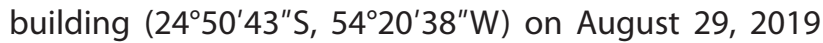
(UTFPR-SH-010). This observation took place about $600 \mathrm{~km}$ from the nearest prior sighting of this species, Serra do Mar, Paraná (Batista, 2015), and is the first documented record of the species outside Paraná's coastal region (Scherer-Neto et al., 2011; Fig. 5). This species inhabits predictable habitats such as flooded grasslands, rice fields, wetlands, and can be easily detected through the playback technique. Its few records in the state denotes a probable underrepresentation and more individuals may be found in specific searches for the species.

\section{Amazona vinacea (Vinaceous-breasted Parrot):} Vulnerable in Paraná (Paraná, 2018). An Atlantic Forest endemic occurring in southeastern Brazil, eastern Paraguay and the province of Misiones in Argentina (Collar et al., 2020). The species has disappeared from most areas in Paraguay and Argentina where they had been historical- ly recorded. Most notably the Itaipu Reserves Complex in Paraguay is of paramount importance for the species (Cockle et al., 2007). The species has a distribution that is quite coincident with that of Araucaria angustifolia (Bertol.) Kuntze. Our observation is one of the few sightings of $A$. vinacea in a Seasonal Semideciduous Forest (Urben-Filho et al., 2008). We saw six individuals flying over the UTFPR-SH campus $\left(24^{\circ} 50^{\prime} 42^{\prime \prime}, 54^{\circ} 20^{\prime} 36^{\prime \prime} \mathrm{W}\right)$ on December 14, 2018 (Fig. 6). They were silent and appeared to be coming from either the Limoy Reserve on the Paraguayan side of the Paraná River or from ARIE-SH.

\section{Herpsilochmus longirostris (Large-billed Antwren):} Its distribution in Brazil extends from the states of Mato Grosso, Tocantins and Goiás, extending to the south of Ceará and south of Piauí, Paraná and São Paulo (Zimmer \& Isler, 2020). Considered endemic to the Brazilian Cerrado (Silva, 1995), it has a characteristic distributions pattern typical of Cerrado species, which arrive in the interior of Paraná traveling down the Paraná River. Known to be found along the banks of the Ivaí and Paraná rivers (Straube \& Urben-Filho, 2005), sightings of this species have been logged approximately $70 \mathrm{~km}$ to the north in Palotina (Osaki, 2016) and 100 km to the north in Guaíra (Freitas, 2011), evidencing their presence in western Paraná. While traversing ARIE-SH's western marginal trail $\left(24^{\circ} 49^{\prime} 59^{\prime \prime} \mathrm{S}, 54^{\circ} 22^{\prime} 04^{\prime \prime} \mathrm{W}\right)$ on June 9, 2017, we saw, photographed (Fig. 7), and recorded their vocalizations. Our record represents the southernmost record of the species in Brazil. 

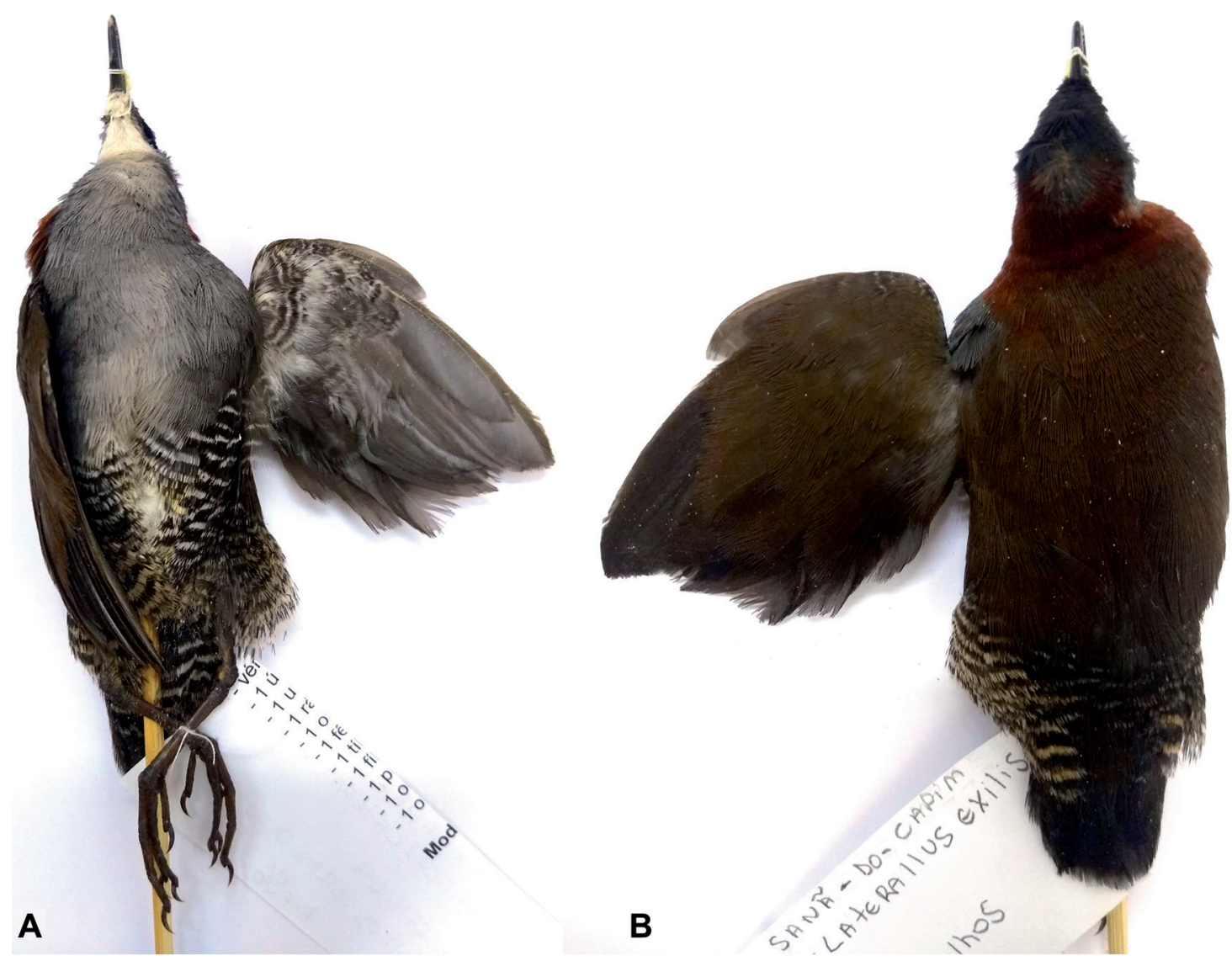

Figure 5. Male Laterallus exilis (UTFPR-56) in ventral (A) and dorsal (B) views registered at the Universidade Tecnológica Federal do Paraná campus, city of Santa Helena.

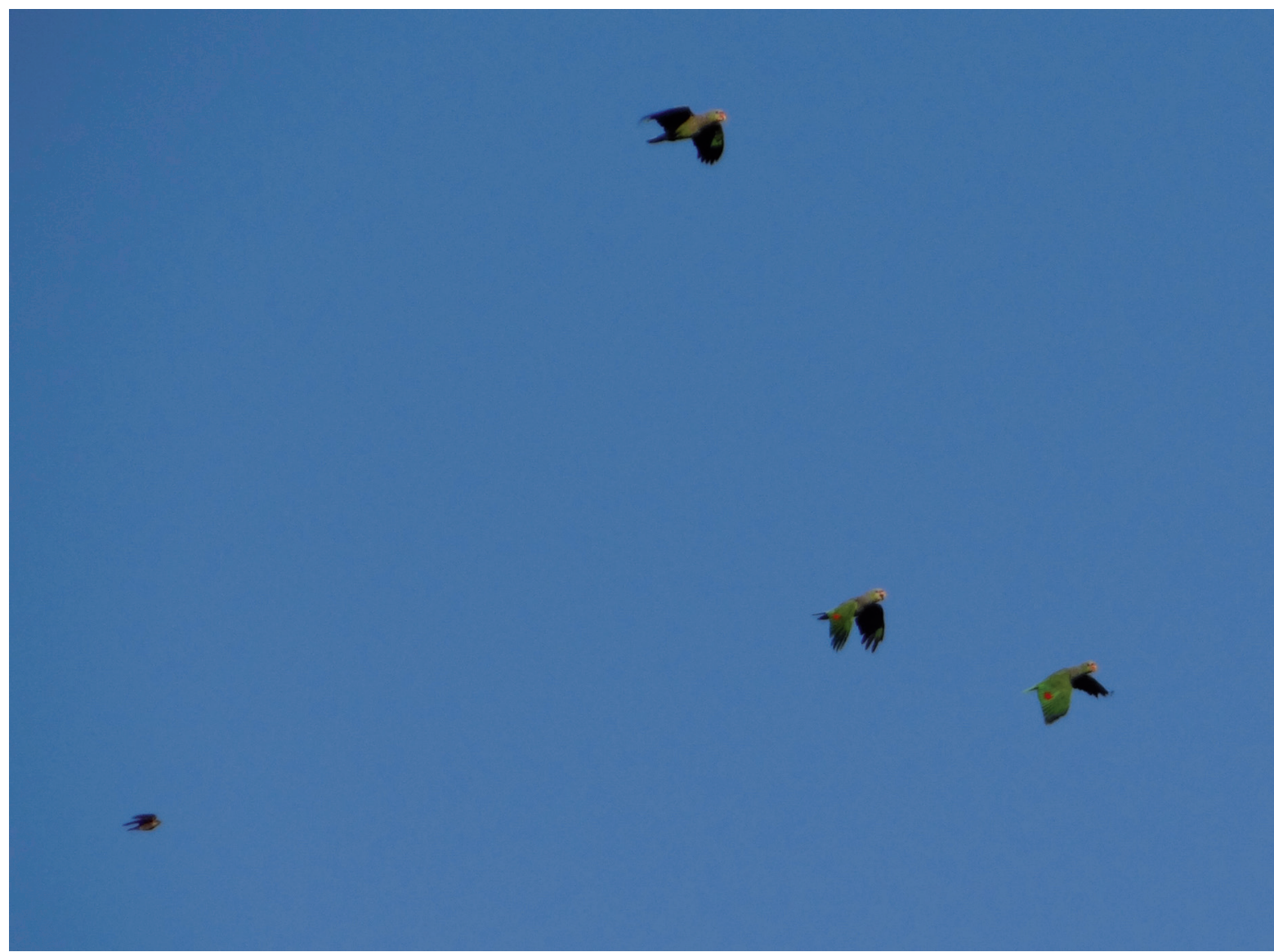

Figure 6. Three of the six Amazona vinacea individuals photographed at the Universidade Tecnológica Federal do Paraná campus, city of Santa Helena (WA4249943). Photo: Vagner Cavarzere. 


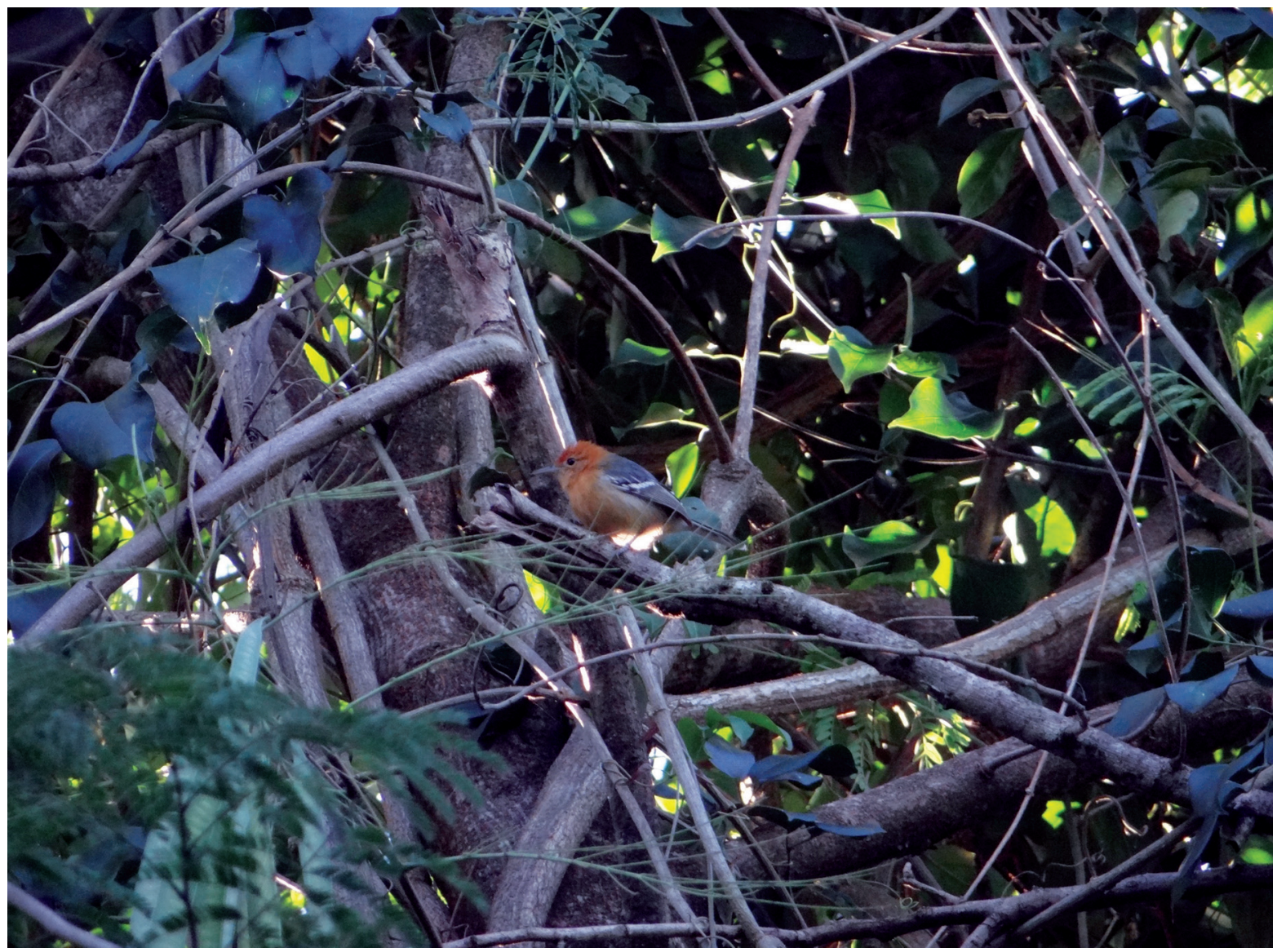

Figure 7. Female Herpsilochmus longirostris photographed at Santa Helena Relevant Ecological Interest Area, Santa Helena County. Photo: Vagner Cavarzere.

\section{Campylorhamphus trochilirostris (Red-billed}

Scythebill): Vulnerable in Paraná (Paraná, 2018), it has the widest distribution of its genus, appearing in all five regions of the country and in 22 Brazilian states (Marantz et al., 2020). Although it has been logged in Paraná's Tibagi River Basin (Anjos et al., 1997), its general distribution pattern indicates that it occurs across Paraná along the Paraná River. Our record is of an individual that collided with a window at the Federal University of Paraná's campus in the city of Palotina and is the southernmost record of this species in Brazil (Fig. 8).

Casiornis rufus (Rufous Casiornis): Vulnerable in Paraná (Paraná, 2018), it is found in Bolivia, central Brazil (Mato Grosso, Goiás, Minas Gerais, Mato Grosso do Sul, Paraná and São Paulo, and recently reported in Rio Grande do Sul), Paraguay and northern Argentina. During the austral winter, it can be found in small numbers in Peru and north and northeastern Brazil (Scholes, 2020). There are few records of the species having been observed in Paraná (Scherer-Neto et al., 2011). We observed two individuals and taped their vocalizations while walking a trail on the east bank of ARIE-SH ( $24^{\circ} 50^{\prime} 43^{\prime \prime} \mathrm{S}, 54^{\circ} 21^{\prime} 40^{\prime \prime} \mathrm{W}$ ) on October 20, 2019 (Fig. 9). Our observation is about $250 \mathrm{~km}$ south of the previous most southern logged observation in the state (Souza, 2019).

Campylorhynchus turdinus (Thrush-like Wren): Found in Brazil's Amazon region, both to the north and south

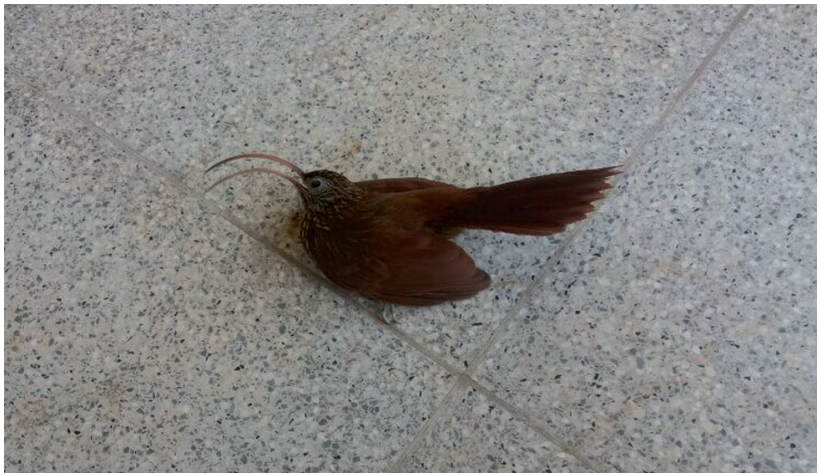

Figure 8. Individual of Campylorhamphus trochilirostris photographed on the Universidade Federal do Paraná campus, city of Palotina. Photo: André Rüdiger.

of the Amazon River, also in the states of Mato Grosso (Pantanal), Bahia and northern Espírito Santo (Kroodsma et al., 2020). It has been suggested that the geographic expansion of the species towards the south is a result not only of deforestation, but also of climate change (Hayes et al., 2018). The first record of the species in Paraná was from the city of Foz do Iguaçu (Bencke et al., 2008), which is an urban environment. We first observed it (Fig. 10) in Santa Helena's city center $\left(24^{\circ} 51^{\prime} 02^{\prime \prime} \mathrm{S}, 54^{\circ} 20^{\prime} 00^{\prime \prime} \mathrm{W}\right)$ on March 10, 2017.

Myiothlypis flaveola (Flavescent Warbler): It ranges mainly through north, south and eastern Brazil (Curson \& Bonan, 2019. The species is typical in dry seasonal for- 


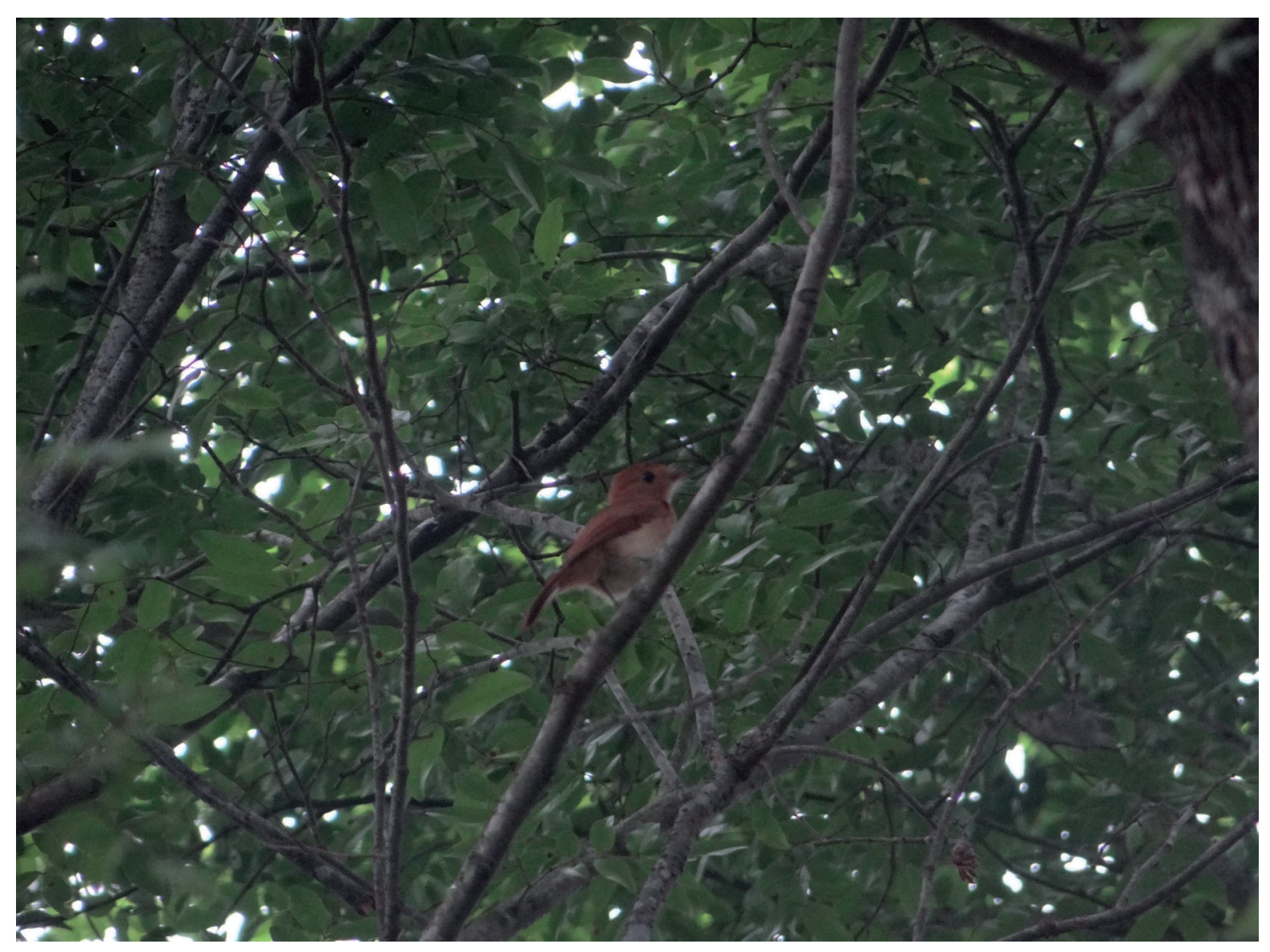

Figure 9. Casiornis rufus photographed at Santa Helena Relevant Ecological Interest Area, Santa Helena County. Photo: Vagner Cavarzere.

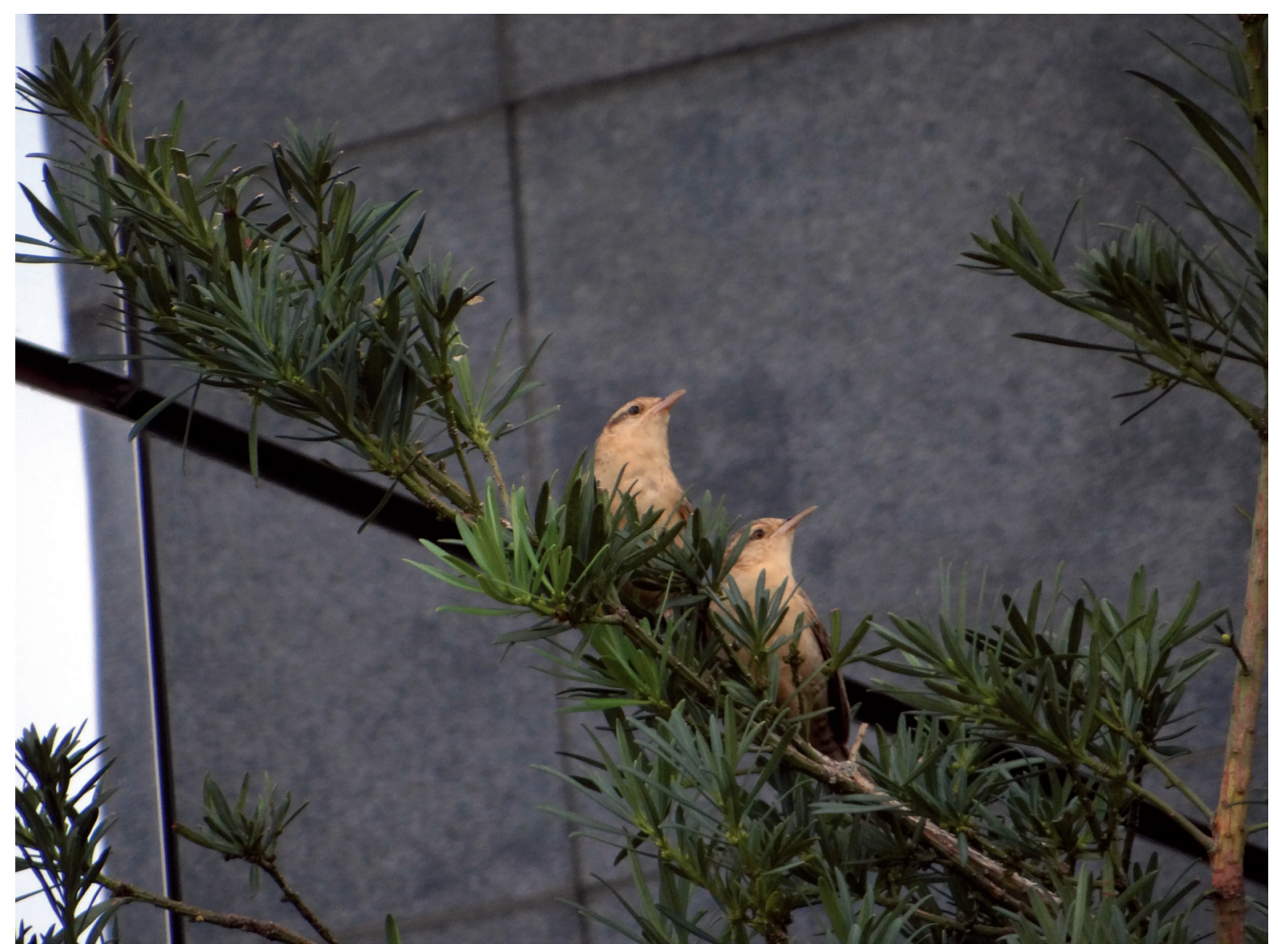

Figure 10. Campylorhynchus turdinus photographed in the city of Santa Helena. Photo: Vagner Cavarzere. 


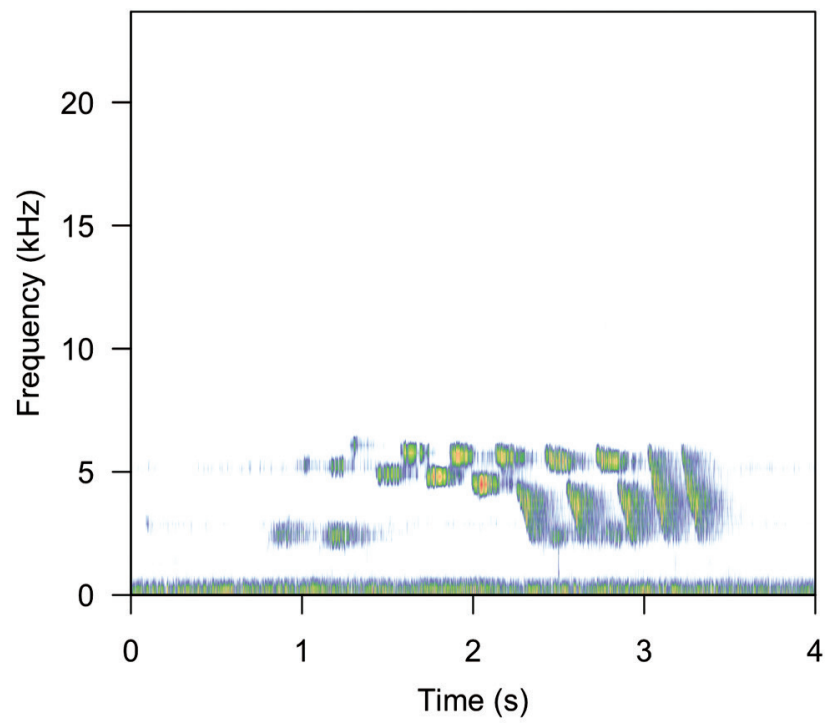

Figure 11. Spectrogram of the vocalization (after playback) of an individual of Myiothlypis flaveola recorded at Santa Helena Relevant Ecological Interest Area, Santa Helena County.

ests found in the country's interior, which includes northeastern Paraná, but has not been previously recorded in western Paraná (Fitzpatrick et al., 2004; Scherer-Neto et al., 2011). Model et al. (2014) reported its presence in an urban fragment of the city of Cascavel $\left(24^{\circ} 57^{\prime} 20^{\prime \prime} \mathrm{S}\right.$, $\left.53^{\circ} 27^{\prime} 19^{\prime \prime} \mathrm{W}\right)$, but this report is not documented. Our record from ARIE-SH ( $\left.24^{\circ} 50^{\prime} 03^{\prime \prime} \mathrm{S}, 54^{\circ} 21^{\prime} 02^{\prime \prime} \mathrm{W}\right)$ represents the southernmost record of the species in Brazil, approximately $150 \mathrm{~km}$ from the previous southernmost documented sighting (Stencel \& Caxambu, 2018). It probably reached western Paraná via the reforested margins of Itaipu Lake. We taped the vocalizations (Fig. 11) of at least two individuals on the $25^{\text {th }}$ of May and $15^{\text {th }}$ of November in 2017 and on the $20^{\text {th }}$ of October in 2019.

Eucometis penicillata (Gray-headed Tanager): This species ranges from western portion of the Brazilian state of Maranhão, to the states of Mato Grosso, Minas Gerais and São Paulo (Hilty, 2020). There are few records of the species from Paraná, and all are centered to the northeast bordering São Paulo state (Scherer-Neto et al., 2011). The previous most southern logged observation was at the Caiuá Ecological Station (SchererNeto et al., 2008, 2011) near the city Diamante do Norte, Paraná. We observed and photographed an individual (Fig. 12) on June 8, 2019, in secondary vegetation at Coluna Prestes $\left(24^{\circ} 52^{\prime} 05^{\prime \prime} \mathrm{S}, 54^{\circ} 13^{\prime} 06^{\prime \prime} \mathrm{W}\right)$ near the city of Diamante d'Oeste, almost $400 \mathrm{~km}$ south of the Caiuá Ecological Station. Our observation is the southernmost for Brazil.

Sporophila palustris (Marsh Seedeater): Critically endangered in Paraná (Paraná, 2018). Sporophila palustris Marsh Seedeater appears in the center and center east and south of Brazil, northern Argentina, and possibly northern Paraguay (Lowen et al., 1996; Jaramillo, 2020;

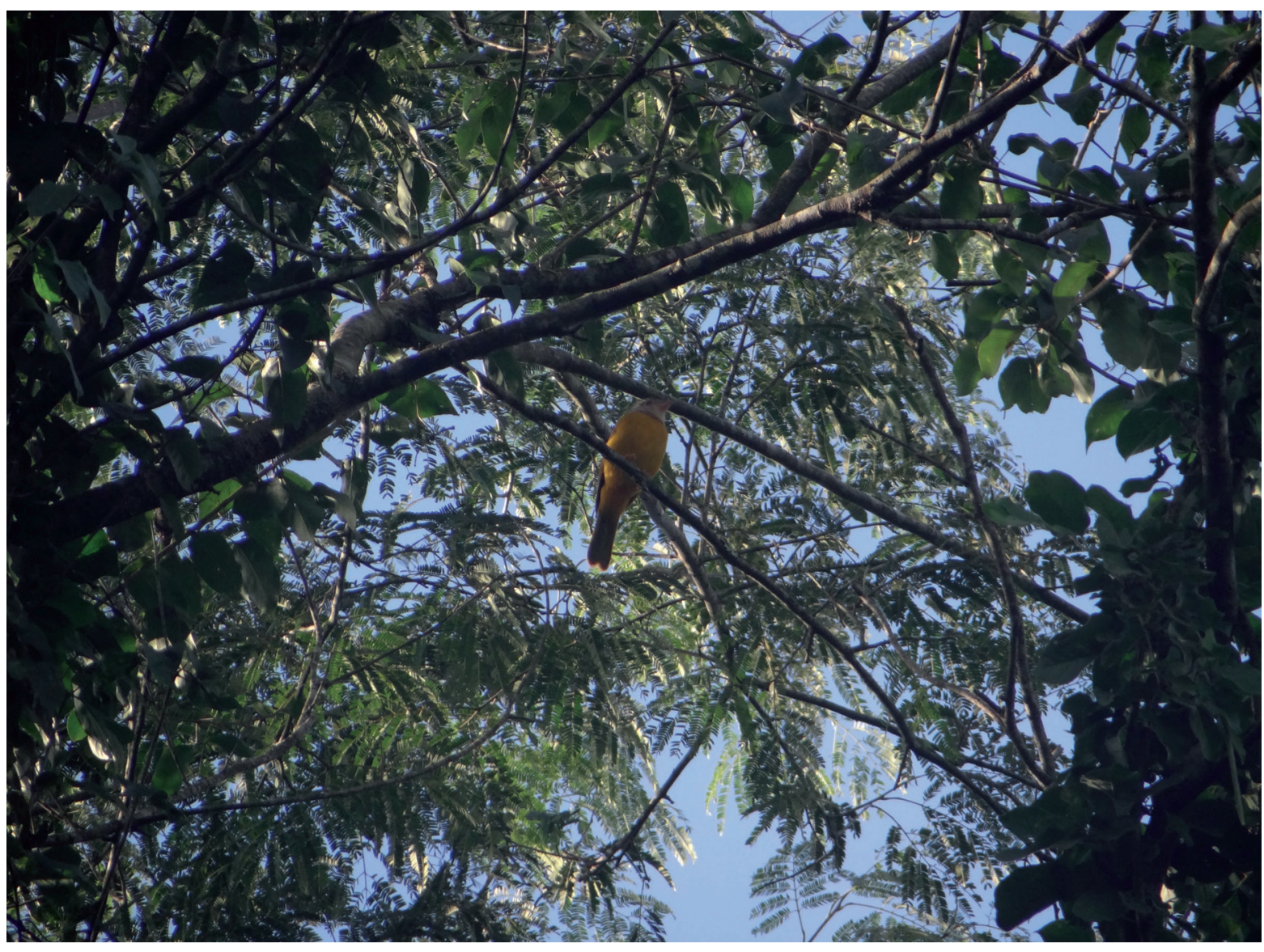

Figure 12. Eucometis penicillata photographed at Coluna Prestes, Diamante d'Oeste County. Photo: Vagner Cavarzere. 


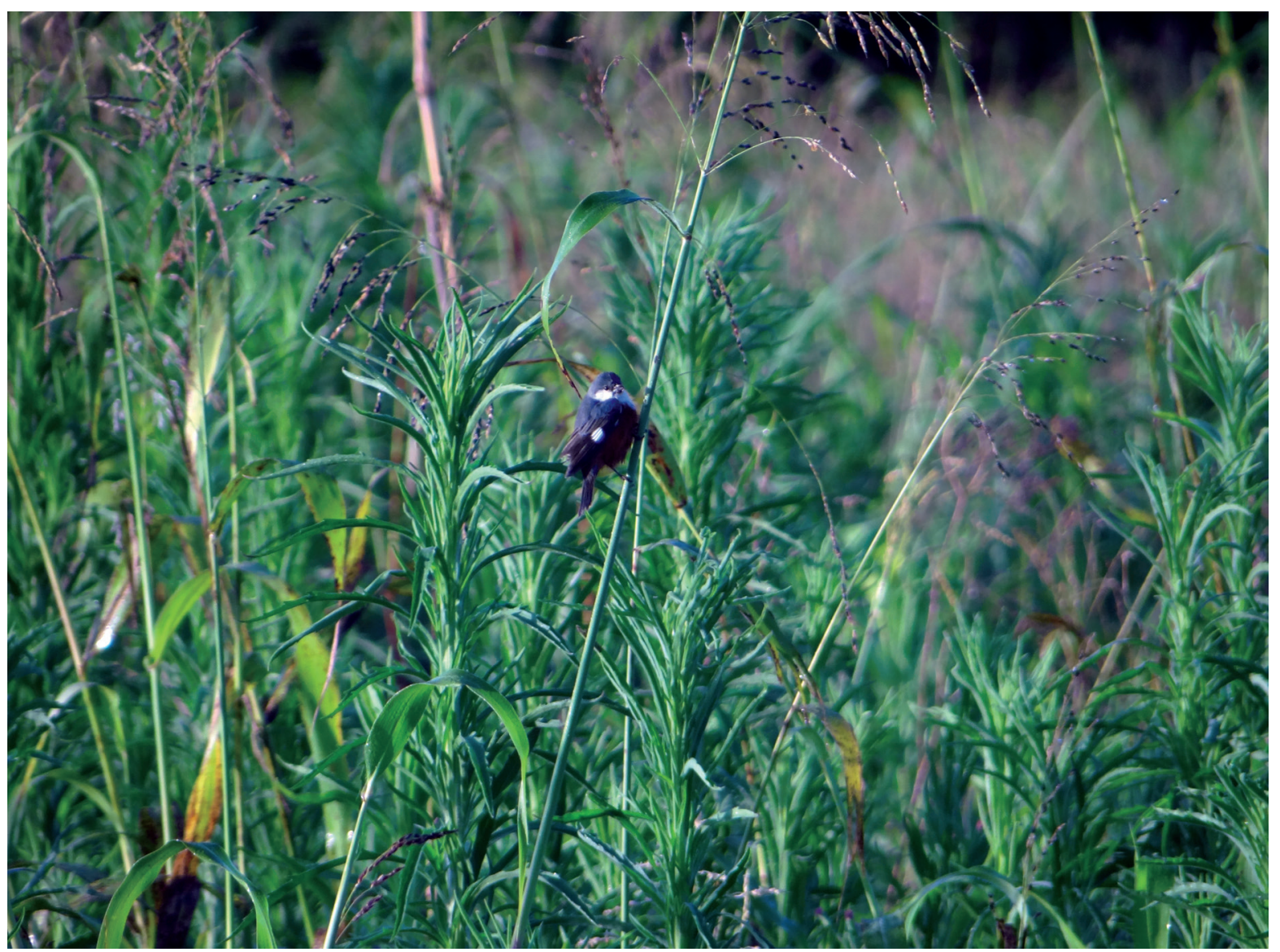

Figure 13. Male Sporophila palustris photographed at the Universidade Tecnológica Federal do Paraná campus, city of Santa Helena. Photo: Vagner Cavarzere.

Vizentin-Bugoni et al., 2013). It breeds in its southern range: Rio Grande do Sul, Brazil, Uruguay, and northern Argentina (BirdLife International, 2017). A sighting of the species in northwestern Paraná was confirmed over two decades ago (Scherer-Neto \& Straube, 1995) and again, much more recently, in eastern Paraná. On November 2, 2016, Paludo (2016) observed two S. palustris individuals in Campina Grande do Sul near Curitiba in eastern Paraná; two days later, we logged and photographed (Fig. 13) one male S. palustris in a small open field on the UTFPR-SH campus. The brief interval and the relatively close proximity of these two S. palustris sightings indicates that flocks of the species were likely migrating south at the beginning of their reproductive season. The individual was among hundreds of S. caerulescens and dozens of $S$. lineola feeding on native the sourgrass Digitaria insularis (L.) Fedde in an area where the exotic 2 m-tall Guinea grass Megathyrsus maximus (Jacq.) predominated $\left(24^{\circ} 50^{\prime} 49^{\prime \prime} \mathrm{S}, 54^{\circ} 20^{\prime} 07^{\prime \prime} \mathrm{W}\right)$. We did not spot S. palustris on following days. These hundreds of other individuals stayed at this location for one week, after which their numbers were significantly lower. We suspect the site served as a resting point while flying over during a migration route. These grasses were cleared in 2017, and new construction has taken their place.

On the same date we also saw two male $S$. collaris and, on the next day, one male S. leucoptera. This S. leucoptera observation was $70 \mathrm{~km}$ south of its previous most southern sighting in Paraná, but our sighting is undocumented.

\section{CONCLUSION}

There is a relatively great amount of information about the birds of ARIE-SH, but most of it was generated more than 30 years ago, rendering this location as extremely under sampled. The terrestrial bird community at ARIE-SH seems to have undergone a major change over the intervening years, especially with respect to species sensitive to habitat modifications. Some terrestrial species were no longer in evidence (large frugivores and understory insectivores), and others were recorded at ARIE-SH for the first time. From our observations, ARIE-SH's aquatic bird community remains relatively unchanged. Although the site had been reasonably well studied, it is of utmost importance to continuously monitor its bird populations to properly document how their community is being affected by habitat modification in the form of flora fragmentation and composition. The changes in the native forest avian species' populations at ARIE-SH reported in our inventories reinforces the importance of avian surveys taking to gauge the effects of severe habitat modification, such as occurred at ARIE-SH, on bird populations, especially endangered species' populations, if the goal of maintaining avian diversity is to be met. 


\section{ACKNOWLEDGMENTS}

To Universidade Tecnológica Federal do Paraná campus Santa Helena for financial and structural support. To Fundação Araucária for a scholarship for ISQ. To Edson Poier for making water censuses possible. To Itaipu Binacional for allowing this study to be conducted. To Pedro Scherer-Neto who contributed to the difficult-to-obtain literature used here. To Luís F. Silveira for kindly allowing access to MZUSP bird collection. Antenor Silva-Júnior kindly contributed with specimens' data deposited under his care. For accompanying us traversing Santa Helena and region: Adriana B. Bussler, Ana P. Zingler, Jonas P. Grigolo, Júlio C.S.M. de Souza, Liamara C. Zagonel, Lucas P. de Oliveira, Nathália L.E. Januário and Sara O.G. Maicrovicz. Data on ARIE-SH were exhaustively collected thanks to the fundamental collaboration of Denise Lange, Edicléia Bonini, Heleno Brandão, Leonardo Biral (who also identified the sourgrass species), Rejane B. de Oliveira and Tatiane Tambarussi. To André Rüdiger who alerted us to the record of $C$. trochilirostris. We thank João Maicrovicz and Jaqueline R. dos Santos for contributing with information during the 2020 coronavirus quarantine period. We extend our gratitude to all citizen scientists who, even unintentionally, greatly contribute to our understanding of Brazilian birds. Dione Seripierri kindly provided difficult-to-find references. We conducted our research according to a SISBio permit (56171-1). Anonymous reviewers greatly contributed to the first draft of this manuscript. Christopher $C$. Fields reviewed the English.

\section{AUTHORS' CONTRIBUTIONS}

I.S.Q.: Conceptualization, Writing - original draft, methodology, data analyses, investigation. Writing - proofreading and editing. V.C.: Supervision, Conceptualization, methodology, data analyses. Writing - proofreading and editing. All authors actively participated in the discussion of the results, reviewed and approved the final version.

\section{REFERENCES}

Alvares, C.A.; Stape, J.L.; Sentelhas, P.C.; de Moraes, G.; Leonardo, J. \& Sparovek, G. 2013. Köppen's climate classification map for Brazil. Meteorologische Zeitschrift, 22(6): 711-728. DOI

Anjos, L. 2001. Bird communities in five Atlantic forest fragments in southern Brazil. Ornitología Neotropical, 12: 11-27.

Anjos, L. 2006. Bird species sensitivity in a fragmented landscape of the Atlantic Forest in southern Brazil. Biotropica, 38(2): 229-234. D0l

Anjos, L. \& Seger, C. 1988. Análise da distribuição das aves em um trecho do rio Paraná, divisa entre os Estados do Paraná e Mato Grosso do Sul. Arquivos de Biologia e Tecnologia, 31(4): 603-612.

Anjos, L.; Schuchmann, K.L. \& Berndt, R. 1997. Avifaunal composition, species richness, and status in the Tibagi river basin, Paraná State, southern Brazil. Ornitología Neotropical, 8: 145-173.
Araya-Salas, M. \& Smith-Vidaurre, G. 2017. warbleR: an $R$ package to streamline analysis of animal acoustic signals. Methods in Ecology and Evolution, 8(2): 184-191. D0I

Athiê, S. \& Dias, M.M. 2012. Frugivoria por aves em um mosaico de Floresta Estacional Semidecidual e reflorestamento misto em Rio Claro, São Paulo, Brasil. Acta Botanica Brasilica, 26(1): 84-93.

Barbosa, K.V.C.; Knogge, C.; Develey, P.F.; Jenkins, C.N. \& Uezu, A. 2017. Use of small Atlantic Forest fragments by birds in Southeast Brazil. Perspectives in Ecology and Conservation, 15(1): 42-46. D0I

Batista, H. 2015. [WA1681272, Laterallus exilis (Temminck, 1831)]. Wiki Aves - A Enciclopédia das Aves do Brasil. Available: http://www.wikiaves. com/1681272. Access: 02/04/2020.

Bencke, G.A.; Dias, R.A. \& Fontana, C.S. 2008. Observações ornitológicas relevantes no Parque Nacional do Iguaçu e arredores, incluindo 0 primeiro registro de Campylorhynchus turdinus para o Paraná. Atualidades Ornitológicas, 145: 6-7.

Bierregaard, R.0.; Kirwan, G.M. \& Boesman, P. 2020. Black-collared Hawk (Busarellus nigricollis). In: Del Hoyo, J.; Elliott, A.; Sargatal, J.; Christie, D.A. \& de Juana, E. (Eds.). Handbook of the Birds of the World Alive. Barcelona, Lynx Edicions. Available: https://www.hbw.com/node/53116. Access: 06/03/2020.

BirdLife International. 2017. Species factsheet: Sporophila palustris. Available: http://www.birdlife.org. Access: 02/04/2020.

Brasil. 2002. Decreto № 4.340, de 22 de agosto de 2002. Regulamenta artigos da Lei № 9.985, de 18 de julho de 2000, que dispõe sobre o Sistema Nacional de Unidades de Conservação da Natureza - SNUC, e dá outras providências. Available: http://www.planalto.gov.br/ccivil 03/decreto/2002/D4340. htm. Access: 07/04/2020.

Brasil. 2014. Portaria № 444, de 17 de dezembro de 2014. Reconhecer como espécies da fauna brasileira ameaçadas de extinção aquelas constantes da Lista Nacional Oficial de Espécies da Fauna Ameaçadas de Extinção. Available: http://www.icmbio.gov.br/portal/images/stories/docs-planode-acao/00-saiba-mais/04 - PORTARIA MMA № 444 DE 17 DE DEZ DE 2014.pdf. Access: 11/04/2020.

Cândido-Jr., J.F.; Snak, C.; Castaldelli, A.P.A.; Brocardo, C.R. \& Model, K.J. 2008. Dieta de avoantes (Zenaida auriculata Des Murs, 1847) atropeladas na BR-277 entre Cascavel e Foz do Iguaçu, PR e implicações para seu manejo. Revista Brasileira de Biociências, 6(S1): 68-69.

Cavarzere, V.; Biral, L.; Oliveira, R.B.; Schneider, E.M.; Lange, D.; Tambarussi, T.; Bonini, E. \& Brandão, H. 2020. Ações de extensão e pesquisa realizadas na Área de Relevante Interesse Ecológico Santa Helena, Estado do Paraná, Brasil. Revista Brasileira de Gestão Ambiental e Sustentabilidade, 7(16): 589-604. DOI

Cockle, K.; Capuzzi, G.; Bodrati, A.; Clay, R.; Del Castillo, H.; Velázquez, M.; Areta, J.I.; Farina, N. \& Farina, R. 2007. Distribution, abundance, and conservation of Vinaceous Amazons (Amazona vinacea) in Argentina and Paraguay. Journal of Field Ornithology, 78(1): 21-39. D01

Collar, N.; Boesman, P. \& de Juana, E. 2020. Vinaceous-breasted Amazon (Amazona vinacea). In: Del Hoyo, J.; Elliott, A.; Sargatal, J.; Christie, D.A. \& de Juana, E. (Eds.). Handbook of the Birds of the World Alive. Barcelona, Lynx Edicions. Available: https://www.hbw.com/species/vinaceousbreasted-amazon-amazona-vinacea. Access: 06/03/2020.

Curson, J. \& Bonan, A. 2019. Flavescent Warbler (Basileuterus Flaveolus). In: Del Hoyo, J.; Elliott, A.; Sargatal, J.; Christie, D.A. \& De Juana, E. (Ed.). Handbook of the birds of the world alive. Barcelona, Lynx Edicions. Disponivel em : https://birdsoftheworld.org/bow/species/flawar1/1.0/ introduction.

Da Silva-Jr., N.J.; Silva, H.L.R.; Costa, M.C.; Buononato, M.A.; Tonial, M.L.S.; Ribeiro, R.S.; Moreira, L.A. \& Pessoa, A.M. 2007. Avaliação preliminar da fauna silvestre terrestre do vale do rio Caiapó, Goiás: Implicações para a 
conservação da biodiversidade regional. Revista EVS - Revista de Ciências Ambientais e Saúde, 34(6): 1057-1094.

Dalmolin, M.F.S.; Malavasi, U.C. \& Malavasi, M.M. 2011. Dispersão e germinação de sementes de Leucaena leucocephala (Lam.) de Wit na região oeste do Paraná. Semina: Ciências Agrárias, 32(1): 55-362. D0I

Freitas, J.A. 2011. [WA479754, Herpsilochmus longirostris Pelzeln, 1868]. In: Wiki Aves - A Enciclopédia das Aves do Brasil. Available: http://www. wikiaves.com/479754. Access: 02/04/2020.

Fitzpatrick, J.W.; Bates, J.M.; Bostwick, K.S.; Caballero, I.C.; Clock, B.M.; Farnsworth, A.; Hosner, P.A.; Joseph, L.; Langham, G.M.; Lebbin, D.J. \& Mobley, J.A. 2004.Family Tyrannidae (tyrant-flycatchers). Handbook of the birds of the world. Barcelon, Lynx. v. 9, p. 170-462.

Fundação SOS Mata Atlântica (SOSMA). 2020. Estudo aponta municípios do Paraná que mais regeneraram a Mata Atlântica. Available: https://www. sosma.org.br/wp-content/uploads/2017/01/Regeneracao-PR-fev17. pdf. Access: 23/12/2020.

Girardi, F. \& Carrano, E. 2014. First records of Masked Tityra Tityra semifasciata (Spix, 1825) for the state of Paraná, southern Brazil. Ornithology Research, 22(4): 416-418. DOI

Gubert-Filho, FA. 2010. 0 desflorestamento no Paraná em um século. In: Sonda, C. \& Trauczynski, S.C. (Orgs.). Reforma agrária e meio ambiente. Curitiba, ITCG. p. 1-25.

Guerrero, A.C. \& Rocha, P.L.B. 2010. Passive restoration in biodiversity hotspots: consequences for an Atlantic Rainforest lizard taxocene. Biotropica, 42(3): 379-387. D0I

Hayes, F.E.; Lecourt, P. \& del Castillo, H. 2018. Rapid southward and upward range expansion of a tropical songbird, the Thrush-like Wren (Campylorhynchus turdinus), in South America: a consequence of habitat or climate change? Ornithology Research, 26(1): 57-64. D0I

Hilty, S. 2020. Grey-headed Tanager (Eucometis penicillata). In: Del Hoyo, J.; Elliott, A.; Sargatal, J.; Christie, D.A. \& de Juana, E. (Eds.). Handbook of the Birds of the World Alive. Barcelona, Lynx Edicions. Available: https:// www.hbw.com/node/61611. Access: 25/03/2020.

lezzi, M.E.; Cruz, P.; Varela, D.; De Angelo, C. \& Di Bitetti, M.S. 2018. Tree monocultures in a biodiversity hotspot: Impact of pine plantations on mammal and bird assemblages in the Atlantic Forest. Forest Ecology And Management, 424: 216-227. D0I

Instituto Brasileiro de Geografia e Estatística (IBGE). 2012. Manual técnico da vegetação brasileira. Rio de Janeiro, IBGE.

International Union for Conservation of Nature and Natural Resources (IUCN). 2019. The IUCN red list of threatened species. Available: https://www. iucnredlist.org. Access: 11/04/2020.

Jaramillo, A. 2020. Marsh Seedeater (Sporophila palustris). In: Del Hoyo, J.; Elliott, A.; Sargatal, J.; Christie, D.A. \& de Juana, E. (Eds.). Handbook of the Birds of the World Alive. Barcelona, Lynx Edicions. Available: https:// www.hbw.com/node/62133. Access: 25/03/2020.

Kliver, S.M. 2010. Plano de Manejo Área de Relevante Interesse Ecológico Santa Helena ARIE-SH Refúgio Biológico Santa Helena RBSH. Santa Helena, Nattural Engenharia Ambiental.

Koeppen, W. 1948. Climatologia: con un estudio de los climas de la tierra. Panuco, Fondo de Cultura Económica.

Krebs, C.J. 1989. Ecological Methodology. New York, Harper \& Row.

Kroodsma, D.; Brewer, D. \& Kirwan, G.M. 2020. Thrush-like Wren (Campylorhynchus turdinus). In: Del Hoyo, J.; Elliott, A.; Sargatal, J.; Christie, D.A. \& de Juana, E. (Eds.). Handbook of the Birds of the World Alive. Barcelona, Lynx Edicions. Available: https://www.hbw.com/ node/58099. Access: 25/03/2020.

Lara, A.I. 1994. Composição da avifauna aquática da margem esquerda do reservatório de Itaipu, Paraná, Brasil. (Masters Dissertation). Curitiba, Universidade Federal do Paraná.
Lowen, J.C.; Bartrina, L.; Brooks, T.M.; Clay, R.P. \& Tobias, J. 1996. Project YACUTINGA'95: bird surveys and conservation priorities in eastern Paraguay. Cotinga, 5: 14-19.

Lindsey, B.R.A.; Bochio, G.M. \& Anjos, L. 2019. Bird species that occupy river edge in continuous forest tend to be less sensitive to forest fragmentation. Ornithology Research, 27(3): 172-186. DOI

MacKenzie, D.I.; Nichols, J.D.; Royle, J.A.; Pollock, K.H.; Bailey, L. \& Hines, J.E. 2017. Occupancy estimation and modeling: inferring patterns and dynamics of species occurrence. Elsevier, Burlington.

Mackinnon, J.R. \& Phillips, K. 1993. A field guide to the Birds of Borneo, Sumatra, Java and Bali. Oxford University Press.

Marantz, C.A.; Aleixo, A.; Bevier, L.R. \& Patten, M.A. 2020. Red-billed Scythebill (Campylorhamphus trochilirostris). In: Del Hoyo, J.; Elliott, A.; Sargatal, J.; Christie, D.A. \& de Juana, E. (Eds.). Handbook of the Birds of the World Alive. Barcelona, Lynx Edicions. Available: https://www.hbw. com/node/56644. Access: 25/03/2020.

Marsden, S.J.; Whiffin, M. \& Galetti, M. 2001. Bird diversity and abundance in forest fragments and Eucalyptus plantations around an Atlantic forest reserve, Brazil. Biodiversity \& Conservation, 10(5): 737-751. D01

Model, K.J.; Remor, M.B. \& do Nascimento, J.E. 2014. Levantamento qualitativo e reprodutivo da ornitofauna dos parques Tarquínio Joslin dos Santos e Parque Ecológico Paulo Gorski, Cascavel, PR. Arquivos de Ciências Veterinárias e Zoologia da UNIPAR, 17(2): 107-114. DOI

Naumburg, E.M.B. 1937. Studies of birds from eastern Brazil and Paraguay, based on a collection made by Emil Kaempfer: Conopophagidae, Rhinocryptidae, Formicariidae (part). Bulletin of the American Museum of Natural History, 74(3): 139-205.

Naumburg, E.M.B. 1939. Studies of birds from eastern Brazil and Paraguay, based on a collection made by Emil Kaempfer: Formicariidae (part). Bulletin of the American Museum of Natural History, 76(6): 231-276.

Oksanen, J.; Kindt, R.; Legendre, P.; O'Hara, B.; Stevens, M.H.H.; Oksanen, M.J. \& Suggests, M.A.S.S. 2007. The vegan package. Community Ecology Package, 10: 631-637.

Osaki, M.R. 2016. [WA2193988, Herpsilochmus longirostris Pelzeln, 1868\}. In: Wiki Aves - A Enciclopédia das Aves do Brasil. Available: http://www. wikiaves.com/2193988. Access: 02/04/2020.

Paludo, F. 2016. [WA2349189, Sporophila palustris (Barrows, 1883)]. In: Wiki Aves - A Enciclopédia das Aves do Brasil. Available: http://www.wikiaves. com/2349189. Access: 06/04/2020.

Paraná. 2018. Decreto № 11.797, de 22 de novembro de 2018. Reconhece e atualiza lista de espécies de aves pertencentes à fauna silvestre ameaçadas de extinção no estado do Paraná e dá outras providências, atendendo o Decreto № 3.148, de 2004. Available: https://www.legislacao.pr.gov.br/ legislacao/listarAtosAno.do?action $=$ exibir\&codAto $=211323 \&$ indice $=1$ \&totalRegistros=272\&anoSpan $=2018 \& a n o S e l e c i o n a d 0=2018 \&$ mesSel ecionado $=11$. Access: 09/2019.

Pearman, M.; Pugnali, G.D.; Casañas, H. \& Bodrati, A. 2000. First records of Grey-breasted Crake Laterallus exilis in Argentina. Cotinga, 13: 79-82.

Pejchar, L.; Gallo, T.; Hooten, M.B. \& Daily, G.C. 2018. Predicting effects of large-scale reforestation on native and exotic birds. Diversity and Distributions, 24(5/6): 811-819. D0I

Pereira-Ribeiro, J.; Ferreguetti, Á.C.; Tomas, W.M.; Bergallo, H.G.; Rocha, C.F.D. \& Brooks, D.M. 2018. The rusty-margined guan (Penelope superciliaris) in the Brazilian Atlantic rain forest: density, population size, activity and habitat use. Wildlife Research, 45(6): 551-558. DOI

Piacentini, V.Q.; Aleixo, A.; Agne, C.E.; Maurício, G.N.; Pacheco, J.F.; Bravo, G.A.; Brito, G.R.R.; Naka, L.N.; Olmos, F.; Posso, S.; Silveira, L.F.; Betini, G.S.; Carrano, E.; Franz, I.; Lees, A.C.; Lima, L.M.; Pioli, D.; Schunck, F.; Amaral, F.R.; Bencke, G.A.; Cohn-Haft, M.; Figueiredo, L.F.A.; Straube, F.C. \& Cesari, E. 2015. Annotated checklist of the birds of Brazil by the Brazilian 
Ornithological Records Committee/Lista comentada das aves do Brasil pelo Comitê Brasileiro de Registros Ornitológicos. Revista Brasileira de Ornitologia, 23(2): 91-298.

Pinto, 0.D.O. \& Camargo, E.D. 1956. Lista anotada de aves colecionadas nos limites ocidentais do estado do Paraná. Papéis Avulsos de Zoologia, 12: 215-234.

Pizo, M.A. 2004. Frugivory and habitat use by fruit-eating birds in a fragmented landscape of southeast Brazil. Ornitología Neotropical, 15(1): 117-126.

Rezende, C.L.; Scarano, F.R.; Assad, E.D.; Joly, C.A.; Metzger, J.P.; Strassburg, B.B.N.; Tabarelli, M.; Fonseca, G.A. \& Mittermeier, R.A. 2018. From hotspot to hopespot: An opportunity for the Brazilian Atlantic Forest. Perspectives in ecology and conservation, 16(4): 208-214. D0I

Ribeiro, M.C.; Metzger, J.P.; Martensen, A.C.; Ponzoni, F.J. \& Hirota, M.M. 2009. The Brazilian Atlantic Forest: How much is left, and how is the remaining forest distributed? Implications for conservation. Biological Conservation, 142(6): 1141-1153. DOI

Ribon, R. 2010. Amostragem de aves pelo método das listas de MacKinnon. In: Matter, S.; Straube, F.C.; de Queiroz Piacentini, V.; Accordi, I.A. \& Cândido-Jr., J.F. 2010. Ornitologia e conservação: ciência aplicada, técnicas de pesquisa e levantamento. Rio de Janeiro, Technical Books. p. 1-16.

Ribon, R.; Simon, J.E. \& Theodoro De Mattos, G. 2003. Bird extinctions in Atlantic forest fragments of the Viçosa region, southeastern Brazil. Conservation Biology, 17(6): 1827-1839. D0I

Santos-Júnior, P.C.A.; Marques, F.C.; Lima, M.L. \& Anjos, L. 2016. The importance of restoration areas to conserve bird species in a highly fragmented Atlantic forest landscape. Natureza \& Conservação, 14: 1-7. DOI

Scherer, L.M.; Zucareli, V.; Zucareli, C.A. \& Fortes, A.M.T. 2005. Efeito alelopático do extrato aquoso de folha e de fruto de leucena (Leucaena leucocephala Wit) sobre a germinação e crescimento de raiz da canafístula (Peltophorum dubium Spreng.). Semina: Ciências Agrárias, 26(2): 161-166.

Scherer-Neto, P. 1983. Avifauna do extinto Parque Nacional de 7 Quedas, Guaíra, estado do Paraná. Arquivos de Biologia e Tecnologia, 26(4): 489-494.

Scherer-Neto, P. 1997. Levantamento da avifauna nos Refúgios Biológicos de Bela Vista e Santa Helena. Curitiba, SPVS.

Scherer-Neto, P. \& Straube, F. 1995. Aves do Paraná: história, lista anotada e bibliografia. Curitiba, Edição dos autores. 79p.

Scherer-Neto, P.; Carrano, E. \& Ribas, C.F. 2008. Composição e conservação da avifauna da Estação Ecológica do Caiuá, noroeste do Paraná e regiões adjacentes. Cadernos da Biodiversidade, 6(1): 32-34.

Scherer-Neto, P.; Straube, F.C.; Carrano, E. \& Urben-Filho, A. 2011. Lista das aves do Paraná. Hori Cadernos Técnicos, 2: 1-130.

Scholes, E. 2020. Rufous Casiornis (Casiornis rufus). In: Del Hoyo, J.; Elliott, A.; Sargatal, J.; Christie, D.A. \& de Juana, E. (Eds.). Handbook of the Birds of the World Alive. Barcelona, Lynx Edicions, Available: https://www.hbw. com/node/57493. Access: 07/04/2020.

Scott, D.A \& Carbonell, M. 1986. A directory of neotropical wetlands. Cambridge, IUCN Conservation Monitoring Centre.

Seger, C.; Lara, A.I.; Arruda, S.D.; Boçón, R.; Antonelli-Filho, R. \& Scherer-Neto, P. 1993. Avifauna dos Refúgios Biológicos de Bela Vista e Santa Helena, Itaipu Binacional, oeste do Paraná. In: Congresso Brasileiro de Ornitologia, $3^{\circ}$. Pelotas Sociedade Brasileira de Ornitologia. Anais. p. 36.

Silva, J.M.C. 1995. Biogeographic analysis of the South American Cerrado avifauna. Steenstrupia, 21: 49-67.

Souza, G.A. 2019. [WA3393963, Casiornis rufus (Vieillot, 1816)]. In: Wiki Aves - A Enciclopédia das Aves do Brasil. Available: http://www.wikiaves. com/3393963. Access: 07/04/2020.
Stencel, L.F. \& Caxambu, M.G. 2018. Avifauna da RPPN Fazenda Moreira Sales, em Goioerê e Moreira Sales, Paraná, Brasil. Atualidades Ornitológicas, 205: 41-48.

Stouffer, P.C.; Johnson, E.I.; Bierregaard-Jr., R.O. \& Lovejoy, T.E. 2011. Understory bird communities in Amazonian rainforest fragments: species turnover through 25 years post-isolation in recovering landscapes. PloS ONE, 6(6): e20543. DOI

Straube, F.C. 1993. Revisão do itinerário da Expedição Natterer ao Estado do Paraná (Brasil). Acta Biologica Leopoldensia, 15(1): 5-20.

Straube, F.C. 2015. Ruinas e Urubus. história da Ornitologia no Paraná. Período de Chrostowski, 1 (1901-1909). Curitiba, Hori Consultoria Ambiental.

Straube, F.C. 2016. Ruínas e urubus: história da ornitologia no Paraná. Período de Chrostowski, 2 (1910). Curitiba, Hori Consultoria Ambiental.

Straube, F.C. 2017. Ruínas e urubus: história da ornitologia no Paraná. Período de Chrostowski, 3 (1910 a 1930). Curitiba, Hori Consultoria Ambiental.

Straube, F.C. \& Bornschein, M.R. 1989. A contribuição de André Mayer à História Natural no Paraná. I. Sobre uma coleção de aves do extremo noroeste do Paraná e sul do Mato Grosso do Sul. Arquivos de Biologia e Tecnologia, 32(4): 441-471.

Straube, F.C. \& Bornschein, M.R. 1995. New or noteworthy records of birds from northwestern Paraná and adjacent areas (Brazil). Bulletin-British Ornithologists (lub, 115(4): 219-225.

Straube, F.C. \& Urben-Filho, A. 2005. Observações sobre a avifauna de pequenos remanescentes florestais na região noroeste do Paraná (Brasil). Atualidades Ornitológicas, 123(10): 10-23.

Straube, F.C.; Urben-Filho, A. \& Cândido-Jr., J.F. 2004. Novas informações sobre a avifauna do Parque Nacional do Iguaçu (Paraná). Atualidades Ornitológicas, 120(10): 1-18.

Sztolcman, J. 1926. Étude des collections ornithologiques de Paraná. In: Annales Zoologici Musei Polonici Historiae Naturalis, 5(3): 107-196.

Tambarussi, T.; Wilhelm, V.E.; Magalhaes, P.S.G. \& Biral, L. 2019. A fuzzy logic model for zone delineation in a preservation area in Brazil. Applied Ecology and Environmental Research, 17(2): 5011-5027. DOI

Taylor, B. 2020. Grey-breasted Crake (Laterallus exilis). In: Del Hoyo, J.; Elliott, A.; Sargatal, J.; Christie, D.A. \& de Juana, E. (Eds.). Handbook of the Birds of the World Alive. Barcelona, Lynx Edicions. Available: https://www. hbw.com/node/53601. Access: 30/03/2020.

The R Project for Statistical Computing (R Core Team). 2019. R: A language and environment for statistical computing.

Urben-Filho, A.; Straube, F.C. \& Carrano, E. 2008. Amazona vinacea. In: Machado, A.B.M.; Drummond, G.M. \& Paglia, A.P. (Eds.). Livro vermelho da fauna brasileira ameaçada de extinção. Brasília, IBAMA. p. 462-464.

Vale, M.M.; Tourinho, L.; Lorini, M.L.; Rajão, H. \& Figueiredo, M.S. 2018. Endemic birds of the Atlantic Forest: traits, conservation status, and patterns of biodiversity. Journal of Field Ornithology, 89(3): 193-206. DOI

Vizentin-Bugoni, J.; Areta, J.I.; Di Giacomo, A.G.; Di Giacomo, A.S.; Jacobs, F.; Coimbra, M.A.A. \& Dias, R.A. 2013. Breeding biology and conservation of the Marsh Seedeater Sporophila palustris. Bird Conservation International, 23(2): 147-158. D0I

Von Matter, S.; Straube, F.C.; de Queiroz Piacentini, V.; Accordi, I.A. \& Cândido-Jr., J.F. 2010. Ornitologia e conservação: ciência aplicada, técnicas de pesquisa e levantamento. Rio de janeiro, Technical Books Editora.

Willis, E.0. 1979. The composition of avian communities in remanescent woodlots in southern Brazil. Papéis Avulsos de Zoologia, 33: 1-25.

Willis, E.0. 2003. Birds of a eucaliptos woodlot in interior São Paulo. Brazilian Journal of Biology, 63(1): 141-158. DOI

Zimmer, K.\& Isler, M.L. 2020. Large-billed Antwren (Herpsilochmus longirostris). In: Del Hoyo, J.; Elliott, A.; Sargatal, J.; Christie, D.A. \& de Juana, E. (Eds.). Handbook of the Birds of the World Alive. Barcelona, Lynx Edicions,. Available: https://www.hbw.com/node/56757. Access: 06/04/2020. 


\section{APPENDIX}

List of bird species recorded within Santa Helena Relevant Ecological Interest Area (ARIE-SH) and surroundings. IFL: Index of Frequency in Lists. DdO: Diamante d'Oeste, SH: municipality of Santa Helena, UTFPR: Universidade Tecnológica Federal do Paraná campus. Documentations are A: aural, P: photographed, R: recording, V: visual. Numbers refer to studies. 1: Scherer-Neto (1986, 1987), 2: Lara (1994), 3: Kliver (2010) and 4: this study. MHNCl = Museu de História Natural Capão da Imbuia, MZUSP = Museu de Zoologia da Universidade de São Paulo.

\begin{tabular}{|c|c|c|c|c|c|c|c|}
\hline Taxa & English name & IFL & ARIE-SH & DdO & SH & UTFPR & Documentation \\
\hline \multicolumn{8}{|l|}{ Tinamiformes } \\
\hline \multicolumn{8}{|l|}{ Tinamidae } \\
\hline Crypturellus obsoletus & Brown Tinamou & & 1,3 & & & & \\
\hline Crypturellus parvirostris & Small-billed Tinamou & & 1,3 & & & & \\
\hline Crypturellus tataupa & Tataupa Tinamou & 0.094 & $1,3,4$ & & & $x$ & $A, R$ \\
\hline Rhynchotus rufescens & Red-winged Tinamou & & $1,3,4$ & $x$ & & $x$ & A \\
\hline Nothura maculosa & Spotted Nothura & & 1,3 & & & & \\
\hline \multicolumn{8}{|l|}{ Anseriformes } \\
\hline \multicolumn{8}{|l|}{ Anatidae } \\
\hline Dendrocygna bicolor & Fulvous Whistling-Duck & & 1,4 & & & & v \\
\hline Dendrocygna viduata & White-faced Whistling-Duck & 0.016 & $1,2,3,4$ & & $x$ & & $\mathrm{~A}, \mathrm{P}, \mathrm{V}$ \\
\hline Cairina moschata & Muscovy Duck & 0.016 & $1,2,3,4$ & & & & $\mathrm{P}, \mathrm{V}$ \\
\hline Sarkidiornis sylvicola & Comb Duck & & 1,3 & & & & \\
\hline Amazonetta brasiliensis & Brazilian Teal & & $1,2,3,4$ & $x$ & & & $\mathrm{~A}, \mathrm{P}, \mathrm{V}$ \\
\hline Anas bahamensis & White-cheeked Pintail & & 1 & & & & \\
\hline Netta erythrophthalma & Southern Pochard & & 3 & & & & \\
\hline Netta peposaca & Rosy-billed Pochard & & 3 & & & & \\
\hline Nomonyx dominicus & Masked Duck & & 1,3 & & & & \\
\hline \multicolumn{8}{|l|}{ Galliformes } \\
\hline \multicolumn{8}{|l|}{ Cracidae } \\
\hline Penelope superciliaris & Rusty-margined Guan & & 3,4 & $x$ & & & $A, V$ \\
\hline \multicolumn{8}{|l|}{ Podicipediformes } \\
\hline \multicolumn{8}{|l|}{ Podicipedidae } \\
\hline Rollandia rolland & White-tufted Grebe & & 3 & & $x$ & & MHNCI \\
\hline Tachybaptus dominicus & Least Grebe & & 1,3 & & & & \\
\hline Podilymbus podiceps & Pied-billed Grebe & & $1,3,4$ & & & & $\mathrm{P}, \mathrm{V}$ \\
\hline \multicolumn{8}{|l|}{ Ciconiiformes } \\
\hline \multicolumn{8}{|l|}{ Ciconiidae } \\
\hline Mycteria americana & Wood Stork & & 3,4 & & & & v \\
\hline \multicolumn{8}{|l|}{ Suliformes } \\
\hline \multicolumn{8}{|l|}{ Phalacrocoracidae } \\
\hline Nannopterum brasilianus & Neotropic Cormorant & & $1,2,4$ & & & & $\mathrm{P}, \mathrm{V}$ \\
\hline \multicolumn{8}{|l|}{ Anhingidae } \\
\hline Anhinga anhinga & Anhinga & & $1,2,4$ & & & & v \\
\hline \multicolumn{8}{|l|}{ Pelecaniformes } \\
\hline \multicolumn{8}{|l|}{ Ardeidae } \\
\hline Tigrisoma lineatum & Rufescent Tiger-Heron & & 3,4 & & & & V \\
\hline Ixobrychus involucris & Stripe-backed Bittern & & 3 & & & & \\
\hline Nycticorax nycticorax & Black-crowned Night-Heron & & $1,2,3$ & & Sítio Paraná & & $P, V$ \\
\hline Butorides striata & Striated Heron & & $1,2,3,4$ & & & & $A, P, V$ \\
\hline Bubulcusibis & Cattle Egret & & $1,2,3,4$ & & & & $P, V$ \\
\hline Ardea cocoi & Cocoi Heron & 0.016 & $1,2,3,4$ & & & & $\mathrm{P}, \mathrm{V}$ \\
\hline Ardea alba & Great Egret & & $1,2,3,4$ & & & & $\mathrm{P}, \mathrm{V}$ \\
\hline Syrigma sibilatrix & Whistling Heron & & $1,3,4$ & & & & $\mathrm{~A}, \mathrm{P}, \mathrm{V}$ \\
\hline Egretta thula & Snowy Egret & & $1,2,3,4$ & & & & $\mathrm{P}, \mathrm{V}$ \\
\hline \multicolumn{8}{|l|}{ Threskiornithidae } \\
\hline Mesembrinibis cayennensis & Green Ibis & 0.016 & 3,4 & $x$ & & & $A, V$ \\
\hline Phimosus infuscatus & Bare-faced lbis & & 4 & $x$ & & & $\mathrm{P}, \mathrm{V}$ \\
\hline \multicolumn{8}{|l|}{ Cathartiformes } \\
\hline \multicolumn{8}{|l|}{ Cathartidae } \\
\hline Cathartes aura & Turkey Vulture & & $1,3,4$ & & & & $\mathrm{P}, \mathrm{V}$ \\
\hline Coragyps atratus & Black Vulture & 0.031 & $1,3,4$ & $x$ & $x$ & & $\mathrm{P}, \mathrm{V}$ \\
\hline
\end{tabular}




\begin{tabular}{|c|c|c|c|c|c|c|c|}
\hline Taxa & English name & IFL & ARIE-SH & DdO & SH & UTFPR & Documentation \\
\hline \multicolumn{8}{|l|}{ Accipitriformes } \\
\hline \multicolumn{8}{|l|}{ Pandionidae } \\
\hline Pandion haliaetus & Osprey & & $1,3,4$ & & & & $\mathrm{P}, \mathrm{V}$ \\
\hline \multicolumn{8}{|l|}{ Accipitridae } \\
\hline Leptodon cayanensis & Gray-headed Kite & & 3 & & & & \\
\hline Elanoides forficatus & Swallow-tailed Kite & & 1,4 & & $x$ & & V \\
\hline Elanus leucurus & White-tailed Kite & & 3,4 & & & $x$ & V \\
\hline Ictinia plumbea & Plumbeous Kite & & 3,4 & & & & V \\
\hline Busarellus nigricollis & Black-collared Hawk & & 4 & & & & V \\
\hline Rostrhamus sociabilis & Snail Kite & & 3,4 & & & & $\mathrm{P}, \mathrm{V}$ \\
\hline Geranospiza caerulescens & Crane Hawk & & 3 & & & & \\
\hline Urubitinga urubitinga & Great Black Hawk & & 3,4 & & & & V \\
\hline Rupornis magnirostris & Roadside Hawk & 0.031 & $1,3,4$ & & $x$ & & $\mathrm{~A}, \mathrm{P}, \mathrm{V}$ \\
\hline Parabuteo leucorrhous & White-rumped Hawk & & 3 & & & & \\
\hline \multicolumn{8}{|l|}{ Gruiformes } \\
\hline \multicolumn{8}{|l|}{ Aramidae } \\
\hline Aramus guarauna & Limpkin & & $2,3,4$ & $x$ & & & $\mathrm{~A}, \mathrm{P}, \mathrm{V}$ \\
\hline \multicolumn{8}{|l|}{ Rallidae } \\
\hline Aramides cajaneus & Gray-necked Wood-Rail & & $1,2,3$ & & & & \\
\hline Aramides saracura & Slaty-breasted Wood-Rail & & $1,2,3,4$ & $x$ & & & $\mathrm{~A}, \mathrm{P}, \mathrm{V}$ \\
\hline Laterallus melanophaius & Rufous-sided Crake & & 3 & & & & \\
\hline Laterallus exilis & Gray-breasted Crake & & & & & $x$ & $s$ \\
\hline Porzana flaviventer & Yellow-breasted Crake & & 3 & & & & \\
\hline Mustelirallus albicollis & Ash-throated Crake & & 3,4 & & & & A \\
\hline Pardirallus nigricans & Blackish Rail & & $1,2,3,4$ & & & & A \\
\hline Gallinula galeata & Common Gallinule & 0.047 & $1,2,3,4$ & & & & $\mathrm{~A}, \mathrm{P}, \mathrm{V}$ \\
\hline Porphyriops melanops & Spot-flanked Gallinule & & 1,3 & & & & \\
\hline Porphyrio martinicus & Purple Gallinule & & $1,2,3,4$ & & & & V \\
\hline Fulica armillata & Red-gartered Coot & & 3 & & & & \\
\hline Fulica leucoptera & White-winged Coot & & 3 & & & & \\
\hline \multicolumn{8}{|l|}{ Heliornithidae } \\
\hline Heliornis fulica & Sungrebe & & 1 & & & & \\
\hline \multicolumn{8}{|l|}{ Charadriiformes } \\
\hline \multicolumn{8}{|l|}{ Charadriidae } \\
\hline Vanellus chilensis & Southern Lapwing & 0.063 & $1,2,3,4$ & & $x$ & & $\mathrm{~A}, \mathrm{P}, \mathrm{V}$ \\
\hline Pluvialis dominica & American Golden-Plover & & 3 & & & & \\
\hline Charadrius collaris & Collared Plover & & 2,3 & & & & \\
\hline \multicolumn{8}{|l|}{ Recurvirostridae } \\
\hline Himantopus melanurus & White-backed Stilt & & $1,2,3,4$ & & & & $P, V$ \\
\hline \multicolumn{8}{|l|}{ Scolopacidae } \\
\hline Gallinago undulata & Giant Snipe & & 3 & & & & \\
\hline Actitis macularius & Spotted Sandpiper & & 4 & & & & $P, V$ \\
\hline Tringa solitaria & Solitary Sandpiper & & $2,3,4$ & & & & $\mathrm{P}, \mathrm{V}$ \\
\hline Tringa melanoleuca & Greater Yellowlegs & & 1,4 & & & & $P, V$ \\
\hline Tringa flavipes & Lesser Yellowlegs & & $1,2,3$ & & & & \\
\hline Calidris fuscicollis & White-rumped Sandpiper & & 2,3 & & & & \\
\hline \multicolumn{8}{|l|}{ Jacanidae } \\
\hline Jacana jacana & Wattled Jacana & 0.016 & $1,2,3,4$ & & & & $\mathrm{~A}, \mathrm{P}, \mathrm{V}$ \\
\hline \multicolumn{8}{|l|}{ Sternidae } \\
\hline Sternula superciliaris & Yellow-billed Tern & & 2 & & & & \\
\hline Phaetusa simplex & Large-billed Tern & & 3,4 & & & $x$ & $A, V$ \\
\hline \multicolumn{8}{|l|}{ Rynchopidae } \\
\hline Rynchops niger & Black Skimmer & & 1,3 & & & & \\
\hline \multicolumn{8}{|l|}{ Columbiformes } \\
\hline Columbidae & & & & & & & \\
\hline Columbina minuta & Plain-breasted Ground-Dove & & 1 & & & & \\
\hline Columbina talpacoti & Ruddy Ground-Dove & 0.078 & $1,3,4$ & $x$ & $x$ & & $\mathrm{~A}, \mathrm{P}, \mathrm{V}$ \\
\hline Columbina squammata & Scaled Dove & & $1,3,4$ & & & & $\mathrm{~A}, \mathrm{P}, \mathrm{V}$ \\
\hline Columbina picui & Picui Ground-Dove & & $1,3,4$ & & & & $\mathrm{~A}, \mathrm{P}, \mathrm{V}$ \\
\hline Claravis pretiosa & Blue Ground-Dove & & 3 & & & & \\
\hline
\end{tabular}




\begin{tabular}{|c|c|c|c|c|c|c|c|}
\hline Taxa & English name & IFL & ARIE-SH & DdO & SH & UTFPR & Documentation \\
\hline Patagioenas picazuro & Picazuro Pigeon & 0.203 & $1,3,4$ & $x$ & $x$ & & $\mathrm{~A}, \mathrm{P}, \mathrm{V}$ \\
\hline Patagioenas cayennensis & Pale-vented Pigeon & & $1,3,4$ & & & & $\mathrm{~A}, \mathrm{P}, \mathrm{V}$ \\
\hline Patagioenas plumbea & Plumbeous Pigeon & & & & $x$ & & $\mathrm{MHNCl}$ \\
\hline Zenaida auriculata & Eared Dove & & $1,3,4$ & $x$ & & & $A, P, V$ \\
\hline Leptotila verreauxi & White-tipped Dove & 0.250 & $1,3,4$ & $x$ & & & $A, P, V$ \\
\hline Leptotila rufaxilla & Gray-fronted Dove & & 1,3 & & & & \\
\hline Geotrygon montana & Ruddy Quail-Dove & & 3 & & & & \\
\hline \multicolumn{8}{|l|}{ Cuculiformes } \\
\hline \multicolumn{8}{|l|}{ Cuculidae } \\
\hline Piaya cayana & Squirrel Cuckoo & & $1,3,4$ & $x$ & & & $\mathrm{~A}, \mathrm{P}, \mathrm{V}$ \\
\hline Coccyzus melacoryphus & Dark-billed Cuckoo & & $1,3,4$ & $x$ & $x$ & & A,P,V,MHNCl \\
\hline Crotophaga major & Greater Ani & & $1,3,4$ & & & & $\mathrm{~A}, \mathrm{P}, \mathrm{V}$ \\
\hline Crotophaga ani & Smooth-billed Ani & 0.031 & $1,3,4$ & & $x$ & & $A, P, V$ \\
\hline Guira guira & Guira Cuckoo & & $1,3,4$ & $x$ & $x$ & & $\mathrm{~A}, \mathrm{P}, \mathrm{V}$ \\
\hline Tapera naevia & Striped Cuckoo & & $1,3,4$ & & & & $A$ \\
\hline Dromococcyx pavoninus & Pavonine Cuckoo & 0.063 & 4 & & & & $A, R$ \\
\hline \multicolumn{8}{|l|}{ Strigiformes } \\
\hline \multicolumn{8}{|l|}{ Tytonidae } \\
\hline Tyto furcata & American Barn 0wl & & 3,4 & & $x$ & & $S$ \\
\hline \multicolumn{8}{|l|}{ Strigidae } \\
\hline Megascops choliba & Tropical Screech-0wl & & $1,3,4$ & & $x$ & $x$ & $A, P, V$ \\
\hline Strix hylophila & Rusty-barred Owl & & 3 & & & & \\
\hline Athene cunicularia & Burrowing $0 \mathrm{wl}$ & & $1,3,4$ & & & & $A, P, V$ \\
\hline \multicolumn{8}{|l|}{ Nyctibiiformes } \\
\hline \multicolumn{8}{|l|}{ Nyctibiidae } \\
\hline Nyctibius griseus & Common Potoo & & 3,4 & & $X$ & $x$ & $\mathrm{~A}, \mathrm{P}, \mathrm{V}, \mathrm{MHNCl}$ \\
\hline \multicolumn{8}{|l|}{ Caprimulgiformes } \\
\hline \multicolumn{8}{|l|}{ Caprimulgidae } \\
\hline Lurocalis semitorquatus & Short-tailed Nighthawk & & 3,4 & & & & $A, V$ \\
\hline Nyctidromus albicollis & Common Pauraque & 0.016 & 3,4 & & & $x$ & $A$ \\
\hline Hydropsalis parvula & Little Nightjar & & 3,4 & & & $x$ & $A$ \\
\hline Hydropsalis torquata & Scissor-tailed Nightjar & & 3 & & & & \\
\hline Podager nacunda & Nacunda Nighthawk & & 3,4 & & $x$ & & $\mathrm{P}, \mathrm{V}$ \\
\hline Chordeiles acutipennis & Lesser Nighthawk & & 3 & & & & \\
\hline \multicolumn{8}{|l|}{ Apodiformes } \\
\hline \multicolumn{8}{|l|}{ Apodidae } \\
\hline Cypseloides senex & Great Dusky Swift & & 1 & & $x$ & & MHNCI,MZUSP \\
\hline Streptoprocne zonaris & White-collared Swift & & 3 & & & & \\
\hline \multicolumn{8}{|l|}{ Trochilidae } \\
\hline Phaethornis pretrei & Planalto Hermit & 0.078 & $1,3,4$ & $x$ & $x$ & $x$ & $A, V$ \\
\hline Phaethornis eurynome & Scale-throated Hermit & & 3 & & & & \\
\hline Florisuga fusca & Black Jacobin & & 4 & & $x$ & & $\mathrm{~A}, \mathrm{P}, \mathrm{V}$ \\
\hline Anthracothorax nigricollis & Black-throated Mango & & 3 & & & & \\
\hline Stephanoxis loddigesii & Violet-crowned Plovercrest & & 3 & & & & \\
\hline Chlorostilbon lucidus & Glittering-bellied Emerald & & 1,3 & & $x$ & & $A, V$ \\
\hline Thalurania glaucopis & Violet-capped Woodnymph & & 3 & & & & \\
\hline Hylocharis chrysura & Gilded Hummingbird & 0.016 & $1,3,4$ & $x$ & $x$ & & $A, P, V$ \\
\hline Leucochloris albicollis & White-throated Hummingbird & & 4 & & $x$ & & $\mathrm{~A}, \mathrm{P}, \mathrm{V}$ \\
\hline Amazilia versicolor & Versicolored Emerald & 0.016 & 1,3 & & & & V \\
\hline \multicolumn{8}{|l|}{ Trogoniformes } \\
\hline \multicolumn{8}{|l|}{ Trogonidae } \\
\hline Trogon surrucura & Surucua Trogon & 0.094 & 3,4 & $x$ & & $x$ & $A, P, V$ \\
\hline Trogon rufus & Black-throated Trogon & & 3 & & & & \\
\hline \multicolumn{8}{|l|}{ Coraciiformes } \\
\hline Alcedinidae & & & & & & & \\
\hline Megaceryle torquata & Ringed Kingfisher & 0.016 & $1,2,3,4$ & $x$ & & & $A, V$ \\
\hline Chloroceryle amazona & Amazon Kingfisher & & $1,2,3,4$ & & & & $\mathrm{~A}, \mathrm{P}, \mathrm{V}$ \\
\hline Chloroceryle americana & Green Kingfisher & & $2,3,4$ & & & & $A, V$ \\
\hline Momotidae & & & & & & & \\
\hline Baryphthengus ruficapillus & Rufous-capped Motmot & & 3 & & Subsede & & $P$ \\
\hline
\end{tabular}




\begin{tabular}{|c|c|c|c|c|c|c|c|}
\hline Taxa & English name & IFL & ARIE-SH & DdO & SH & UTFPR & Documentation \\
\hline \multicolumn{8}{|l|}{ Galbuliformes } \\
\hline \multicolumn{8}{|l|}{ Bucconidae } \\
\hline Nystalus chacuru & White-eared Puffbird & & 3 & & & & \\
\hline \multicolumn{8}{|l|}{ Piciformes } \\
\hline \multicolumn{8}{|l|}{ Ramphastidae } \\
\hline Selenidera maculirostris & Spot-billed Toucanet & & 3 & & & & \\
\hline Pteroglossus castanotis & Chestnut-eared Aracari & 0.078 & 3,4 & & $x$ & & $\mathrm{~A}, \mathrm{P}, \mathrm{V}$ \\
\hline \multicolumn{8}{|l|}{ Picidae } \\
\hline Picumnus temminckii & Ochre-collared Piculet & 0.031 & $1,3,4$ & $x$ & & & $\mathrm{~A}, \mathrm{P}, \mathrm{V}$ \\
\hline Melanerpes candidus & White Woodpecker & & 3,4 & & $x$ & & $A, V$ \\
\hline Melanerpes flavifrons & Yellow-fronted Woodpecker & & 3 & & & & \\
\hline Veniliornis spilogaster & White-spotted Woodpecker & 0.047 & $1,3,4$ & & & $x$ & $\mathrm{~A}, \mathrm{P}, \mathrm{V}$ \\
\hline Piculus aurulentus & White-browed Woodpecker & & 1,3 & & & & \\
\hline Colaptes melanochloros & Green-barred Woodpecker & & $1,3,4$ & & & $x$ & $A, V$ \\
\hline Colaptes campestris & Campo Flicker & & $1,3,4$ & $x$ & & & $A, V$ \\
\hline Celeusflavescens & Blond-crested Woodpecker & 0.031 & 3,4 & & & $x$ & $A, P, V$ \\
\hline Dryocopus lineatus & Lineated Woodpecker & & 3 & & & & \\
\hline Campephilus robustus & Robust Woodpecker & & 3 & & & & \\
\hline \multicolumn{8}{|l|}{ Falconiformes } \\
\hline \multicolumn{8}{|l|}{ Falconidae } \\
\hline Caracara plancus & Southern Caracara & & $1,3,4$ & & & & $\mathrm{~A}, \mathrm{P}, \mathrm{V}$ \\
\hline Milvago chimachima & Yellow-headed Caracara & & $1,3,4$ & & $x$ & & $\mathrm{~A}, \mathrm{P}, \mathrm{V}$ \\
\hline Herpetotheres cachinnans & Laughing Falcon & & 3 & & & & \\
\hline Micrastur semitorquatus & Collared Forest-Falcon & 0.016 & 3,4 & & & $x$ & $A, R$ \\
\hline Falco sparverius & American Kestrel & & 1,3 & & $x$ & & $A, V$ \\
\hline Falco rufigularis & Bat Falcon & & 3 & & & & $\mathrm{P}, \mathrm{V}$ \\
\hline Falco femoralis & Aplomado Falcon & & 3,4 & & & $x$ & V \\
\hline Falco peregrinus & Peregrine Falcon & & 1,3 & & & & \\
\hline \multicolumn{8}{|l|}{ Psittaciformes } \\
\hline \multicolumn{8}{|l|}{ Psittacidae } \\
\hline Ara chloropterus & Red-and-green Macaw & & 3 & & & & \\
\hline Psittacara leucophthalmus & White-eyed Parakeet & & $1,3,4$ & & & & A \\
\hline Pyrrhura frontalis & Maroon-bellied Parakeet & & 3 & & & & \\
\hline Myiopsitta monachus & & & & & $x$ & & $A, V$ \\
\hline Forpus xanthopterygius & Blue-winged Parrotlet & & 1,3 & & & & \\
\hline Brotogeris chiriri & Yellow-chevroned Parakeet & 0.063 & 3,4 & & $x$ & & $\mathrm{~A}, \mathrm{P}, \mathrm{V}$ \\
\hline Pionopsitta pileata & Pileated Parrot & & 1,3 & & & & \\
\hline Pionus maximiliani & Scaly-headed Parrot & & 3 & & & & \\
\hline Amazona vinacea & Vinaceous-breasted Parrot & & 3,4 & & & $x$ & $\mathrm{P}, \mathrm{V}$ \\
\hline Amazona aestiva & Turquoise-fronted Parrot & & 3,4 & & & $x$ & A \\
\hline \multicolumn{8}{|l|}{ Passeriformes } \\
\hline \multicolumn{8}{|l|}{ Thamnophilidae } \\
\hline Dysithamnus mentalis & Plain Antvireo & & 3 & & & & \\
\hline Herpsilochmus longirostris & Large-billed Antwren & & 4 & & & & $A, P, R, V$ \\
\hline Thamnophilus doliatus & Barred Antshrike & 0.016 & 4 & $x$ & $x$ & & $A, P, V$ \\
\hline Thamnophilus ruficapillus & Rufous-capped Antshrike & & 3 & & & & \\
\hline Thamnophilus caerulescens & Variable Antshrike & 0.219 & $1,3,4$ & $x$ & & & $A, P, V$ \\
\hline Taraba major & Great Antshrike & & 3 & & & & \\
\hline Mackenziaena leachii & Large-tailed Antshrike & & 3 & & & & \\
\hline Pyriglena leucoptera & White-shouldered Fire-eye & & 1 & & & & \\
\hline Drymophila malura & Dusky-tailed Antbird & & 1 & & & & \\
\hline \multicolumn{8}{|l|}{ Conopophagidae } \\
\hline Conopophaga lineata & Rufous Gnateater & & 1,3 & $x$ & & & $A, V$ \\
\hline \multicolumn{8}{|l|}{ Formicariidae } \\
\hline Chamaeza campanisona & Short-tailed Antthrush & & 3 & & & & \\
\hline \multicolumn{8}{|l|}{ Dendrocolaptidae } \\
\hline Sittasomus griseicapillus & Olivaceous Woodcreeper & & 3 & & & & \\
\hline Campylorhamphus trochilirostris & Red-billed Scythebill & & & & UFPR Palotina & & $P$ \\
\hline Dendrocolaptes platyrostris & Planalto Woodcreeper & & 1,3 & & & & \\
\hline Xiphocolaptes albicollis & White-throated Woodcreeper & & 3 & & & & \\
\hline
\end{tabular}




\begin{tabular}{|c|c|c|c|c|c|c|c|}
\hline Taxa & English name & IFL & ARIE-SH & DdO & SH & UTFPR & Documentation \\
\hline \multicolumn{8}{|l|}{ Furnariidae } \\
\hline Furnarius rufus & Rufous Hornero & 0.031 & $1,3,4$ & $x$ & $X$ & & $\mathrm{~A}, \mathrm{P}, \mathrm{V}$ \\
\hline Phleocryptes melanops & Wren-like Rushbird & & 1 & & & & \\
\hline Automolus leucophthalmus & White-eyed Foliage-gleaner & & & $x$ & & & $A, V$ \\
\hline Philydor rufum & Buff-fronted Foliage-gleaner & & 3 & & & & \\
\hline Certhiaxis cinnamomeus & Yellow-chinned Spinetail & 0.016 & $1,3,4$ & & & & $\mathrm{~A}, \mathrm{P}, \mathrm{V}$ \\
\hline Synallaxis ruficapilla & Rufous-capped Spinetail & & 3 & & & & \\
\hline Synallaxis cinerascens & Gray-bellied Spinetail & & 3 & & & & \\
\hline Synallaxis frontalis & Sooty-fronted Spinetail & 0.016 & $1,3,4$ & $x$ & & & $A, R$ \\
\hline Synallaxis spixi & Spix's Spinetail & & 1,3 & & & & \\
\hline \multicolumn{8}{|l|}{ Pipridae } \\
\hline Pipra fasciicauda & Band-tailed Manakin & & & $x$ & & & $A, P, R, V$ \\
\hline Chiroxiphia caudata & Swallow-tailed Manakin & & 3 & & & & \\
\hline \multicolumn{8}{|l|}{ Tityridae } \\
\hline Schiffornis virescens & Greenish Schiffornis & & 3 & & & & \\
\hline Tityra inquisitor & Black-crowned Tityra & & 3 & & & & \\
\hline Tityra cayana & Black-tailed Tityra & & 3 & & & & \\
\hline Pachyramphus viridis & Green-backed Becard & & 3 & & & & \\
\hline Pachyramphus castaneus & Chestnut-crowned Becard & & 3 & & & & \\
\hline Pachyramphus validus & Crested Becard & 0.016 & 3,4 & $x$ & & $x$ & $A, P, V$ \\
\hline \multicolumn{8}{|l|}{ Cotingidae } \\
\hline Pyroderus scutatus & Red-ruffed Fruitcrow & & 3 & & & & \\
\hline \multicolumn{8}{|l|}{ Platyrinchidae } \\
\hline Platyrinchus mystaceus & White-throated Spadebill & & 3 & & & & \\
\hline \multicolumn{8}{|l|}{ Rhynchocyclidae } \\
\hline Mionectes rufiventris & Gray-hooded Flycatcher & & 3 & & & & \\
\hline Leptopogon amaurocephalus & Sepia-capped Flycatcher & 0.125 & 3,4 & $X$ & & & $\mathrm{~A}, \mathrm{P}, \mathrm{V}$ \\
\hline Corythopis delalandi & Southern Antpipit & 0.234 & 3,4 & $x$ & & & $A, P, V$ \\
\hline Phylloscartes ventralis & Mottle-cheeked Tyrannulet & & 3 & & & & \\
\hline Tolmomyias sulphurescens & Yellow-olive Flycatcher & & 3,4 & & & & $A$ \\
\hline Todirostrum cinereum & Common Tody-Flycatcher & 0.047 & 4 & $X$ & $X$ & & $\mathrm{~A}, \mathrm{P}, \mathrm{V}$ \\
\hline Poecilotriccus plumbeiceps & Ochre-faced Tody-Flycatcher & & 1,3 & & & & \\
\hline Myiornis auricularis & Eared Pygmy-Tyrant & & 3 & $x$ & & & $\mathrm{~A}, \mathrm{P}, \mathrm{V}$ \\
\hline Hemitriccus diops & Drab-breasted Pygmy-Tyrant & & 3 & & & & \\
\hline Hemitriccus obsoletus & Brown-breasted Pygmy-Tyrant & & 3 & & & & \\
\hline Hemitriccus margaritaceiventer & Pearly-vented Tody-tyrant & 0.016 & 3,4 & $x$ & & & $A, P, V$ \\
\hline \multicolumn{8}{|l|}{ Tyrannidae } \\
\hline Euscarthmus meloryphus & Tawny-crowned Pygmy-Tyrant & & 1,3 & & & & \\
\hline Camptostoma obsoletum & Southern Beardless-Tyrannulet & & $1,3,4$ & & & & $\mathrm{~A}, \mathrm{P}, \mathrm{V}$ \\
\hline Elaenia sp. & & & $x$ & & $S$ & & MHNCl \\
\hline Elaenia flavogaster & Yellow-bellied Elaenia & & $1,3,4$ & & $X$ & & $\mathrm{~A}, \mathrm{P}, \mathrm{V}$ \\
\hline Elaenia spectabilis & Large Elaenia & 0.016 & 4 & & $x$ & & $A, P, V, S$ \\
\hline Elaenia mesoleuca & Olivaceous Elaenia & & 4 & & & & $A, R$ \\
\hline Myiopagis caniceps & Gray Elaenia & 0.016 & 4 & $x$ & & & $A, P, R, V$ \\
\hline Myiopagis viridicata & Greenish Elaenia & 0.047 & 4 & $x$ & & & $A, P, R, V$ \\
\hline Capsiempis flaveola & Yellow Tyrannulet & 0.063 & 1,4 & $x$ & & & $A, P, R, V$ \\
\hline Phaeomyias murina & Mouse-colored Tyrannulet & 0.016 & 4 & & & & $A, P, R, V$ \\
\hline Pseudocolopteryx flaviventris & Warbling Doradito & & 3 & & & & \\
\hline Serpophaga subcristata & White-crested Tyrannulet & & $1,3,4$ & & $x$ & & $A, P, R, V$ \\
\hline Legatus leucophaius & Piratic Flycatcher & & 3 & & & & \\
\hline Ramphotrigon megacephalum & Large-headed Flatbill & & 3 & & & & \\
\hline Myiarchus swainsoni & Swainson's Flycatcher & & 1,3 & & & & \\
\hline Myiarchus ferox & Short-crested Flycatcher & 0.031 & 3,4 & & & & $\mathrm{~A}, \mathrm{P}, \mathrm{V}$ \\
\hline Myiarchus tyrannulus & Brown-crested Flycatcher & 0.047 & 3 & & & & $A$ \\
\hline Sirystes sibilator & Sibilant Sirystes & & 1,3 & & & & \\
\hline Casiornis rufus & Rufous Casiornis & & 4 & & & & $\mathrm{~A}, \mathrm{P}, \mathrm{V}$ \\
\hline Pitangus sulphuratus & Great Kiskadee & 0.188 & $1,3,4$ & $x$ & $x$ & & $A, P, V$ \\
\hline Machetornis rixosa & Cattle Tyrant & & $1,3,4$ & & $x$ & & $\mathrm{~A}, \mathrm{P}, \mathrm{V}$ \\
\hline Myiodynastes maculatus & Streaked Flycatcher & 0.031 & $1,3,4$ & $x$ & $x$ & & $A, P, V$ \\
\hline Megarynchus pitangua & Boat-billed Flycatcher & 0.141 & $1,3,4$ & $x$ & $X$ & & $A, P, V$ \\
\hline
\end{tabular}




\begin{tabular}{|c|c|c|c|c|c|c|c|}
\hline Taxa & English name & IFL & ARIE-SH & DdO & SH & UTFPR & Documentation \\
\hline Myiozetetes similis & Social Flycatcher & 0.109 & 1,4 & $x$ & $x$ & & $\mathrm{~A}, \mathrm{P}, \mathrm{V}$ \\
\hline Tyrannus melancholicus & Tropical Kingbird & 0.016 & $1,3,4$ & $x$ & $x$ & & $A, P, V$ \\
\hline Tyrannus savana & Fork-tailed Flycatcher & & $1,3,4$ & & $x$ & & $\mathrm{~A}, \mathrm{P}, \mathrm{V}$ \\
\hline Empidonomus varius & Variegated Flycatcher & 0.016 & 3,4 & $x$ & $x$ & & $A, P, V$ \\
\hline Colonia colonus & Long-tailed Tyrant & & 3 & & & & \\
\hline Myiophobus fasciatus & Bran-colored Flycatcher & 0.016 & 1,3 & & & & A \\
\hline Pyrocephalus rubinus & Vermilion Flycatcher & & 3 & & & & \\
\hline Fluvicola albiventer & Black-backed Water-Tyrant & & $1,3,4$ & & & & $P, V$ \\
\hline Arundinicola leucocephala & White-headed Marsh Tyrant & & $1,3,4$ & & & & $\mathrm{P}, \mathrm{V}$ \\
\hline Cnemotriccus fuscatus & Fuscous Flycatcher & 0.250 & $1,3,4$ & $x$ & & & $\mathrm{~A}, \mathrm{P}, \mathrm{R}, \mathrm{V}, \mathrm{MHNCl}$ \\
\hline Lathrotriccus euleri & Euler's Flycatcher & 0.125 & 3,4 & & & & $A, R$ \\
\hline Contopus cinereus & Tropical Pewee & & 3 & & & & \\
\hline Knipolegus cyanirostris & Blue-billed Black-Tyrant & & & $x$ & & & $\mathrm{~A}, \mathrm{P}, \mathrm{V}$ \\
\hline Hymenops perspicillatus & Spectacled Tyrant & & 3 & & & & \\
\hline Satrapa icterophrys & Yellow-browed Tyrant & & 3 & & & & \\
\hline \multicolumn{8}{|l|}{ Vireonidae } \\
\hline Cyclarhis gujanensis & Rufous-browed Peppershrike & 0.047 & 3,4 & $x$ & & & $\mathrm{~A}, \mathrm{P}, \mathrm{V}$ \\
\hline Vireo chivi & Chivi Vireo & 0.078 & $1,3,4$ & $x$ & & & $A, R$ \\
\hline \multicolumn{8}{|l|}{ Corvidae } \\
\hline Cyanocorax chrysops & Plush-crested Jay & 0.063 & $1,3,4$ & $x$ & & & $\mathrm{~A}, \mathrm{P}, \mathrm{V}$ \\
\hline \multicolumn{8}{|l|}{ Hirundinidae } \\
\hline Pygochelidon cyanoleuca & Blue-and-white Swallow & & 1,3 & & $x$ & & $\mathrm{~A}, \mathrm{~V}$ \\
\hline Stelgidopteryx ruficollis & Southern Rough-winged Swallow & & $1,3,4$ & & & & $\mathrm{~A}, \mathrm{P}, \mathrm{V}$ \\
\hline Progne tapera & Brown-chested Martin & & $1,3,4$ & & $x$ & $x$ & $\mathrm{~A}, \mathrm{P}, \mathrm{V}$ \\
\hline Progne chalybea & Gray-breasted Martin & & 1,3 & $x$ & $x$ & & $\mathrm{~A}, \mathrm{P}, \mathrm{V}$ \\
\hline Tachycineta albiventer & White-winged Swallow & & 1,3 & & & & \\
\hline Tachycineta leucorrhoa & White-rumped Swallow & & $1,3,4$ & & & & V \\
\hline Hirundo rustica & Barn Swallow & & 1,3 & & & & \\
\hline Petrochelidon pyrrhonota & Cliff Swallow & & 1,3 & & & & \\
\hline \multicolumn{8}{|l|}{ Troglodytidae } \\
\hline Troglodytes musculus & Southern House Wren & 0.125 & $1,3,4$ & $x$ & $x$ & & $\mathrm{~A}, \mathrm{P}, \mathrm{V}$ \\
\hline Campylorhynchus turdinus & Thrush-like Wren & & & & $x$ & & $A, P, R, V$ \\
\hline \multicolumn{8}{|l|}{ Donacobiidae } \\
\hline Donacobius atricapilla & Black-capped Donacobius & 0.016 & 3,4 & & & & $A, P, V$ \\
\hline \multicolumn{8}{|l|}{ Turdidae } \\
\hline Turdus leucomelas & Pale-breasted Thrush & 0.234 & $1,3,4$ & $x$ & $x$ & & $A, P, V$ \\
\hline Turdus rufiventris & Rufous-bellied Thrush & 0.031 & $1,3,4$ & $x$ & & & $\mathrm{~A}, \mathrm{P}, \mathrm{V}$ \\
\hline Turdus amaurochalinus & Creamy-bellied Thrush & 0.031 & $1,3,4$ & $x$ & & & $\mathrm{~A}, \mathrm{P}, \mathrm{V}$ \\
\hline Turdus subalaris & Eastern Slaty Thrush & & 3 & & & & \\
\hline Turdus albicollis & White-necked Thrush & & 3 & & & & \\
\hline \multicolumn{8}{|l|}{ Mimidae } \\
\hline Mimus saturninus & Chalk-browed Mockingbird & & $1,3,4$ & & $x$ & & $A, P, V$ \\
\hline Mimus triurus & White-banded Mockingbird & & 3 & & & & \\
\hline \multicolumn{8}{|l|}{ Motaciliidae } \\
\hline Anthus lutescens & Yellowish Pipit & & & & Morro dos Sete Pecados & & $\mathrm{A}, \mathrm{P}, \mathrm{V}$ \\
\hline Anthus hellmayri & Hellmayr's Pipit & & 1,3 & & & & \\
\hline \multicolumn{8}{|l|}{ Passerelidae } \\
\hline Zonotrichia capensis & Rufous-collared Sparrow & & 1,3 & & $x$ & & A \\
\hline Ammodramus humeralis & Grassland Sparrow & & 1,3 & & & & A \\
\hline Arremon flavirostris & Saffron-billed Sparrow & 0.234 & $1,3,4$ & $x$ & & & $\mathrm{~A}, \mathrm{P}, \mathrm{V}, \mathrm{MHNCl}$ \\
\hline \multicolumn{8}{|l|}{ Parulidae } \\
\hline Setophaga pitiayumi & Tropical Parula & 0.078 & 3,4 & $x$ & & & $A, V$ \\
\hline Geothlypis aequinoctialis & Masked Yellowthroat & & $1,3,4$ & & & & $A, V$ \\
\hline Basileuterus culicivorus & Golden-crowned Warbler & 0.359 & $1,3,4$ & $x$ & & & $\mathrm{~A}, \mathrm{P}, \mathrm{V}$ \\
\hline Myiothlypis flaveola & Flavescent Warbler & 0.047 & 4 & & & & $A, R, V$ \\
\hline Myiothlypis leucoblephara & White-browed Warbler & & 3 & & & & \\
\hline \multicolumn{8}{|l|}{ Icteridae } \\
\hline Procacicus solitarius & Solitary Black Cacique & & 3 & & & & \\
\hline Cacicus haemorrhous & Red-rumped Cacique & 0.063 & 3,4 & $x$ & $x$ & $x$ & $A, P, R, V$ \\
\hline Icterus pyrrhopterus & Variable Oriole & & $1,3,4$ & $x$ & $x$ & & $\mathrm{~A}, \mathrm{P}, \mathrm{V}$ \\
\hline
\end{tabular}




\begin{tabular}{|c|c|c|c|c|c|c|c|}
\hline Taxa & English name & IFL & ARIE-SH & Ddo & SH & UTFPR & Documentation \\
\hline Gnorimopsar chopi & Chopi Blackbird & & 3 & & & & \\
\hline Agelasticus cyanopus & Unicolored Blackbird & & 3 & & & & \\
\hline Chrysomus ruficapillus & Chestnut-capped Blackbird & & 1,3 & & & & \\
\hline Molothrus oryzivorus & Giant Cowbird & & 4 & & & & $\mathrm{P}, \mathrm{V}$ \\
\hline Molothrus bonariensis & Shiny Cowbird & 0.016 & $1,3,4$ & & $X$ & & $\mathrm{~A}, \mathrm{P}, \mathrm{V}$ \\
\hline Sturnella superciliaris & White-browed Meadowlark & & $1,3,4$ & & & $x$ & $\mathrm{~A}, \mathrm{P}, \mathrm{V}$ \\
\hline \multicolumn{8}{|l|}{ Thraupidae } \\
\hline Pipraeidea melanonota & Fawn-breasted Tanager & & 3,4 & $x$ & & & $\mathrm{~A}, \mathrm{P}, \mathrm{V}$ \\
\hline Pipraeidea bonariensis & Blue-and-yellow Tanager & & & & $X$ & & $P, V$ \\
\hline Cissopis leverianus & Magpie Tanager & & 3 & & & & \\
\hline Schistochlamys ruficapillus & Cinnamon Tanager & & 3 & & & & \\
\hline Paroaria capitata & Yellow-billed Cardinal & & & & & & V \\
\hline Tangara sayaca & Sayaca Tanager & & $1,3,4$ & $x$ & $X$ & & $\mathrm{~A}, \mathrm{P}, \mathrm{V}$ \\
\hline Tangara palmarum & Palm Tanager & & & & $x$ & & $\mathrm{~A}, \mathrm{~V}$ \\
\hline Tangara cayana & Burnished-buff Tanager & 0.031 & $1,3,4$ & $x$ & $X$ & & $\mathrm{~A}, \mathrm{P}, \mathrm{V}$ \\
\hline Conirostrum speciosum & Chestnut-vented Conebill & 0.047 & 3,4 & $x$ & & & $\mathrm{~A}, \mathrm{P}, \mathrm{V}$ \\
\hline Sicalis flaveola & Saffron Finch & & 3,4 & & & & $\mathrm{~A}, \mathrm{P}, \mathrm{V}$ \\
\hline Haplospiza unicolor & Uniform Finch & & 3 & & & & \\
\hline Hemithraupis guira & Guira Tanager & & 3 & & & & \\
\hline Hemithraupis ruficapilla & Rufous-headed Tanager & & 3 & & & & \\
\hline Volatinia jacarina & Blue-black Grassquit & & 1,3 & $x$ & & & $\mathrm{~A}, \mathrm{P}, \mathrm{V}$ \\
\hline Eucometis penicillata & Gray-headed Tanager & & & $x$ & & & $\mathrm{P}, \mathrm{V}$ \\
\hline Trichothraupis melanops & Black-goggled Tanager & 0.031 & $1,3,4$ & & & & $A, R, V$ \\
\hline Coryphospingus cucullatus & Red-crested Finch & 0.031 & $1,3,4$ & $x$ & & & $A, P, V$ \\
\hline Tachyphonus coronatus & Ruby-crowned Tanager & 0.016 & $1,3,4$ & $x$ & & & $A, P, R, V$ \\
\hline Tersina viridis & Swallow Tanager & 0.016 & 3,4 & & $X$ & $x$ & $A$ \\
\hline Dacnis cayana & Blue Dacnis & 0.047 & 3,4 & $x$ & $X$ & & $A, P, V$ \\
\hline Coereba flaveola & Bananaquit & & & & $X$ & $x$ & $A, V$ \\
\hline Sporophila collaris & Rusty-collared Seedeater & & 3,4 & & & $x$ & $A, P, V$ \\
\hline Sporophila nigricollis & Yellow-bellied Seedeater & & 3 & & & & \\
\hline Sporophila caerulescens & Double-collared Seedeater & & $1,3,4$ & $x$ & & & $A, P, V$ \\
\hline Sporophila leucoptera & White-bellied Seedeater & & & & & $x$ & V \\
\hline Sporophila palustris & Marsh Seedeater & & & & & $x$ & $P, V$ \\
\hline Sporophila angolensis & Chestnut-bellied Seed-Finch & & 1 & & & & \\
\hline Saltator similis & Green-winged Saltator & 0.016 & 3,4 & & & & $A, V$ \\
\hline Thlypopsis sordida & Orange-headed Tanager & & 3 & & & & \\
\hline Pyrrhocoma ruficeps & Chestnut-headed Tanager & & 3 & & & & \\
\hline \multicolumn{8}{|l|}{ Cardinalidae } \\
\hline Habia rubica & Red-crowned Ant-Tanager & & 3 & & & & \\
\hline Cyanoloxia glaucocaerulea & Glaucous-blue Grosbeak & & 3 & & & & \\
\hline Cyanoloxia brissonii & Ultramarine Grosbeak & & 1,3 & & & & \\
\hline \multicolumn{8}{|l|}{ Fringiliidae } \\
\hline Spinus magellanicus & Hooded Siskin & & 1,3 & & & & \\
\hline Euphonia chlorotica & Purple-throated Euphonia & 0.078 & 3,4 & $x$ & $X$ & & $A, P, R, V$ \\
\hline Euphonia violacea & Violaceous Euphonia & & 3 & & & & \\
\hline Euphonia chalybea & Green-throated Euphonia & & 3 & & & & \\
\hline \multicolumn{8}{|l|}{ Estrildidae } \\
\hline Estrilda astrild & Common Waxbill & & & & $x$ & $x$ & A \\
\hline \multicolumn{8}{|l|}{ Passeridae } \\
\hline Passer domesticus & House Sparrow & & 3,4 & & $X$ & & $P, V$ \\
\hline
\end{tabular}

